\title{
Geological setting, petrology and mineralogy of metabasites in a thermal aureole of Tanvald granite (northern Bohemia) used for the manufacture of Neolithic tools
}

\author{
Petr ŠíDA*, Václav KACHLíK \\ Institute of Geology and Palaeontology, Faculty of Science, Charles University in Prague, Albertov 6, Prague 2, Czech Republic; \\ petrsida@seznam.cz \\ ${ }^{*}$ Corresponding author
}

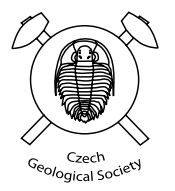

This study examined the metabasites in a thermal aureole of the Tanvald granite in the northern part of the Bohemian Massif that were used for manufacturing Neolithic tools. The metabasites form relatively thin bodies from several $\mathrm{cm}$ to $2 \mathrm{~m}$ thick and are intercalated conformably within the host metasedimentary rocks. Two types of thermally metamorphosed actinolite-hornblende hornfelses (metabasites) were distinguished: 1) fine-grained amphibole-rich metabasite and 2) metabasites with relicts of porphyritic texture. Because of their large lateral extent and geological setting within metasediments, fine-grained metabasites may correspond to former volcanoclastic rocks (meta-tuffs), while the porphyritic metabasites probably represent metamorphosed dolerite sills or dykes. The host rocks are various types of cordieritebiotite spotted schists or andalusite-cordierite-biotite hornfelses. Both groups of metabasites consist of several types of amphiboles, calcic plagioclase (andesine to labradorite) and ilmenite, variably replaced by their alteration products. Apatite, alteration products of ilmenite, magnetite and sulphides are common accessory phases, while epidote and titanite are present only rarely. Relicts of magmatic minerals and minerals from older metamorphic stages are scarce. The peak contact metamorphic conditions were constrained between 540 and $600{ }^{\circ} \mathrm{C}$. Sample of charcoal taken from the base of the Neolithic quarry, where a large amount of waste from making of semi-finished polished tools was found, was dated by radiocarbon dating technique. It gave an age of VERA-2981 $6120 \pm 35 \mathrm{BP}$, which places the sampling location in one of the closing stages of quarrying in this part of the site.

The correspondence of the petrological and mineralogical characteristics of metabasites from the thermal aureole and stone tools found in Germany and southern Moravia provided evidence that Neolithic tools were traded over distances of several hundred kilometres.

Keywords: amphibole hornfels, stone tool, Neolith, Tanvald granite, Krkonoše-Jizera Crystalline Unit, Bohemian Massif Received: 3 March 2008; accepted 29 May 2009; handling editor: J. Konopásek

\section{Introduction}

Because of their suitable physical properties (strength, density, lack of cleavability, grindability etc.), usage value and relative availability, fine-grained metabasites were sought-after raw materials from the Mesolithic up to the Late Neolithic times. In addition, because their distribution on the Earth's surface is very random, the tools manufactured from these materials were transported over long distances (more than $500 \mathrm{~km}$ ) from the source of the raw materials to densely populated areas settled by cultures that used the stone artefacts mainly for farming purposes (Christensen et al. 2006). Stone artefacts manufactured from several metabasite types were common mainly in the Early to Middle Neolithic periods in Central Europe (see Christensen et al. 2006 for reference). With the onset of the metal use in the Late Neolithic period, the production of stone tools declined.

The thermal aureole of the Tanvald granite (Fig. 1) is one of several places in Central Europe where it is possible to study the raw materials that were used for the production of Neolithic stone tools together with preserved archaeological sites in which the finished tools were exploited. These sites have been dated to approximately 7000 years BP (Šrein et al. 2002; Prostředník et al. 2005; Šída 2005; 2007a, b). The current study employs geological, petrological and mineralogical methods to obtain detailed characteristics of metabasites from natural and artificial outcrops in the thermal aureole of Tanvald granite. It thus extends the research performed by Klomínský et al. (2004) at the Rádlo locality to a much broader area of the thermal aureole between Rádlo and Plavy. Several new natural or artificial outcrops of these spectacular rocks were discovered, together with new archaeological sites, where the raw material for production of stone tools was quarried. This activity was dated using the radiocarbon dating technique and by archaeological methods.

In addition, this study investigated artefacts found at archaeological sites in the thermal aureole of the Tanvald 


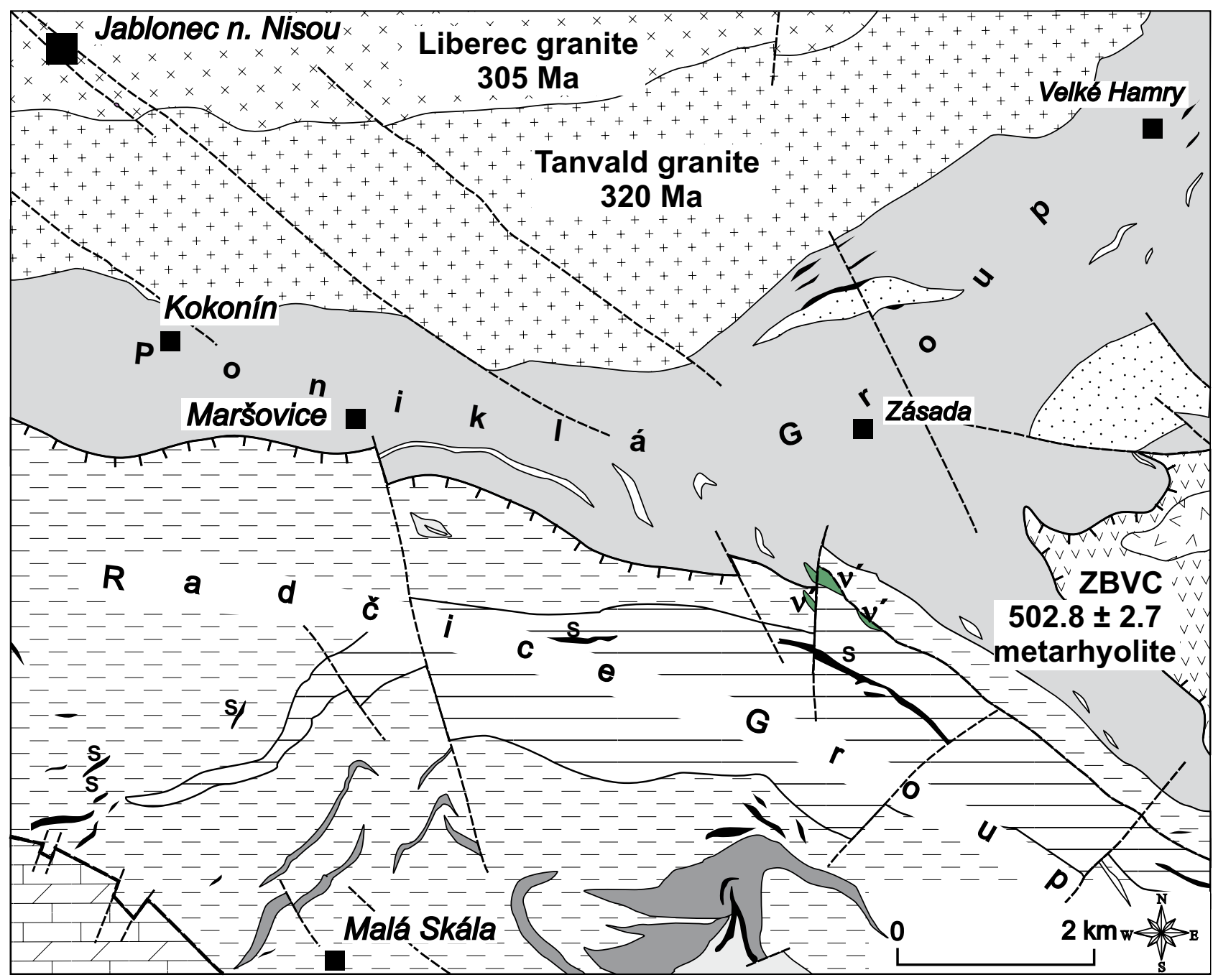

platform cover

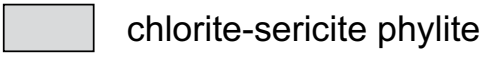

chlorite-albite phyllite

$\Longrightarrow$ quartzite

metadolerite,

fine-grained metabasite

sericite-chlorite phyllite

roofing phyllite, chloritoid-bearing
S serpentinite

$v^{\prime}$ metagabbro

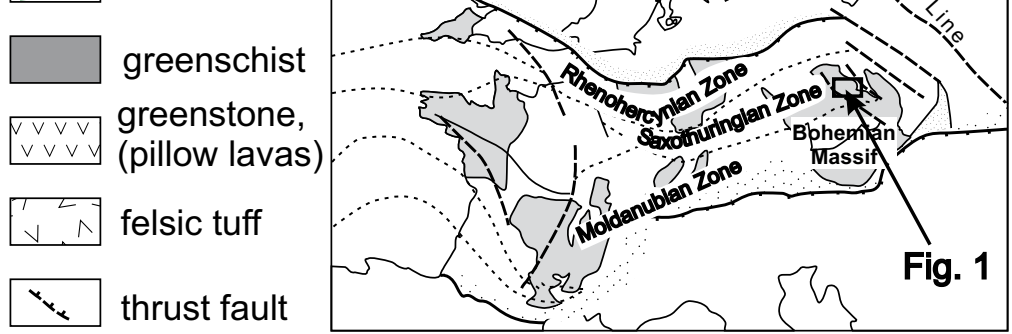

\. fault

Fig. 1 Simplified geological map of the contact of the Krkonoše-Jizera Pluton with volcano-sedimentary rocks of the Železný Brod Crystalline Unit (according to Kachlík in Klomínský et al. 2006). ZBVC - Železný Brod Volcanic Complex.

granite and compared them with basaltic artefacts found at archaeological sites in Bohemia and Moravia. The mineralogical and textural data will serve for evaluation and provenance analysis of artefacts from the archaeological sites in all of the Central Europe, where hornblendeactinolite hornfelses of basaltic composition are common (Schwarz and Schneider 1983). The results of this study may provide information for the inference of possible 
Neolithic trade routes, the estimation of the volume of goods traded, and, possibly, the documentation of the changes in the settlement distribution.

\section{History of metabasite research}

Metabasite from the Tanvald granite thermal aureole has been known since the beginning of the $20^{\text {th }}$ century (Milch 1902; Huyer 1914, 1928; Gränzer 1933). Huyer (1914) and Gränzer (1933) published the petrographic description of the rocks, referring to them as nephrite, and were the first to notice that these rocks were used for manufacturing Neolithic tools. The search for a source of metabasite artefacts similar to Gränzer's "nephrite", found in great numbers in eastern and central Bohemia, once again focussed the attention of geologists and archaeologists to northern Bohemia (Přrichystal 1991; Bukovanská 1992). Later, mineralogical and petrographic comparison of metabasites from the aureole of the Tanvald granite with Neolithic artefacts widespread in Bohemia and Moravia made it possible to locate the source of metabasites to the area of the Tanvald granite between Velké Hamry and Maršovice (Šrein et al. 2002; Přichystal 2002; Šreinová et al. 2005) (Figs 2-3).

Several outcrops of hornblende-actinolite hornfelses (metabasites) were found during geological mapping of map sheet 03-322 - Jablonec nad Nisou in 1997-2000 and were later described in the explanatory text accompanying the map (Kachlík in Klomínský et al. 2006). During the present archaeological research, artefacts and evidence demonstrating the Neolithic mining and manufacturing of stone tools have been found at several archaeological sites in the area of Jistebsko and Maršovický vrch on the southern slope of the Černá Studnice ridge (Šrein et al. 2003; Prostředník et al. 2005; Šída 2004a, b) (Figs 2-3). New artificial exposures of metabasites were made in the southwesternmost continuation of the metabasite belt during excavation for the construction of a waste disposal site close to Rádlo village (Klomínský et al. 2004).

\section{Geological setting of metabasites}

\subsection{Stratigraphic position of metabasites and host metasediments within the Krkonoše-Jizera Crystalline Unit}

The Krkonoše-Jizera Crystalline Unit (KJCU) is one of the largest crustal units in the West Sudetes terrane mosaic (Narebski 1994; Cymmerman et al. 1997; Żelaźniewicz 1997; Franke 1989; Franke et al. 1993; Franke and Żelaźniewicz 2000; Mazur et al. 2006). The West Sudetes at the NE margin of the Bohemian Massif are interpreted as the easternmost part of the Saxothuringian Zone of the Variscan orogen (Franke et al. 1993). West Sudetes are composed of Late Proterozoic to Early Carboniferous low- to medium-grade metasedimentary and metavolcano-sedimentary sequences that were intruded by granitoid bodies of Late Proterozoic as well as Early and Late Palaeozoic ages (Svoboda and Chaloupský

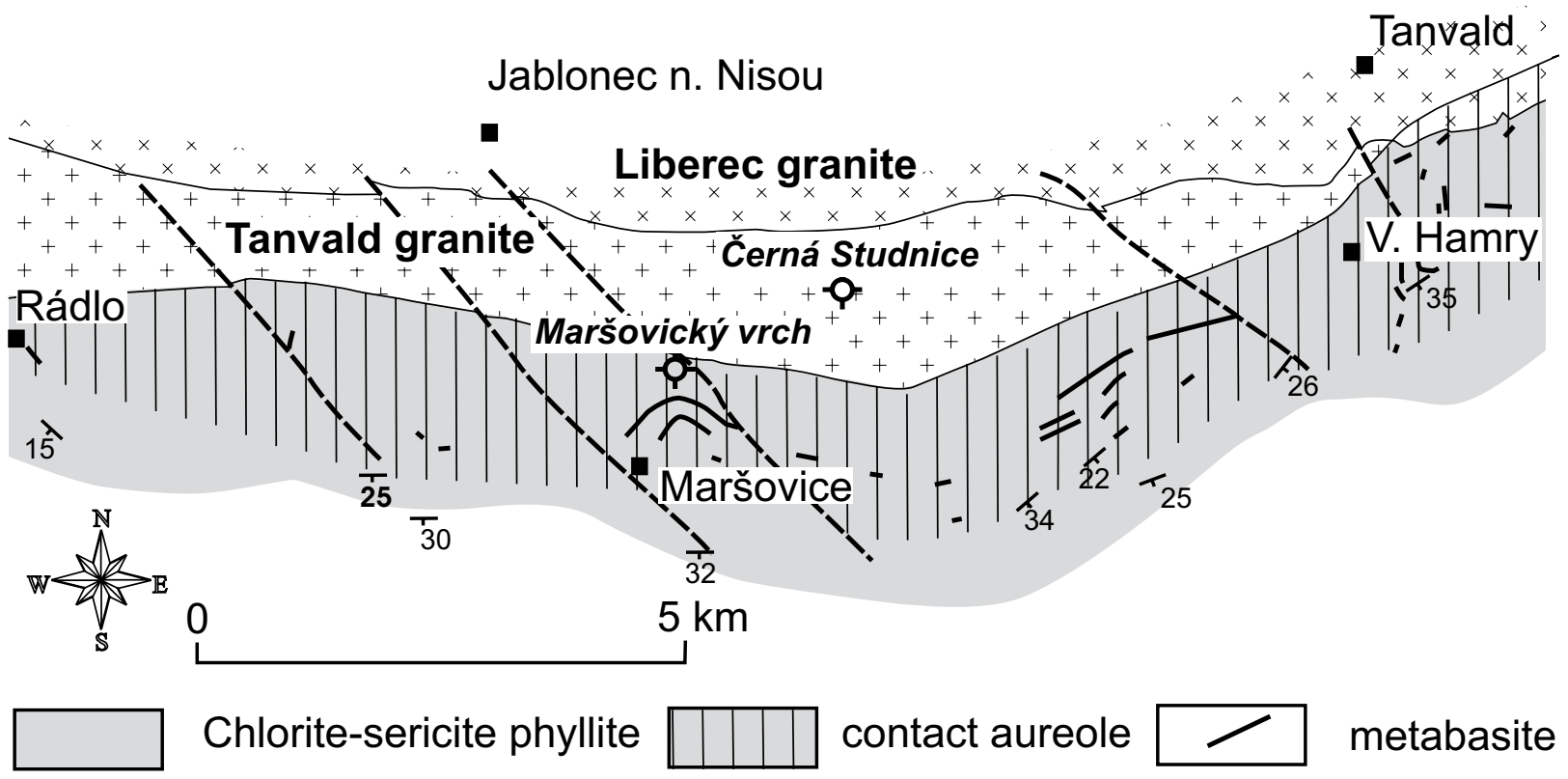

Fig. 2 Map of metabasite occurrences in the thermal aureole of Tanvald granite (modified after Šída 2007a). 


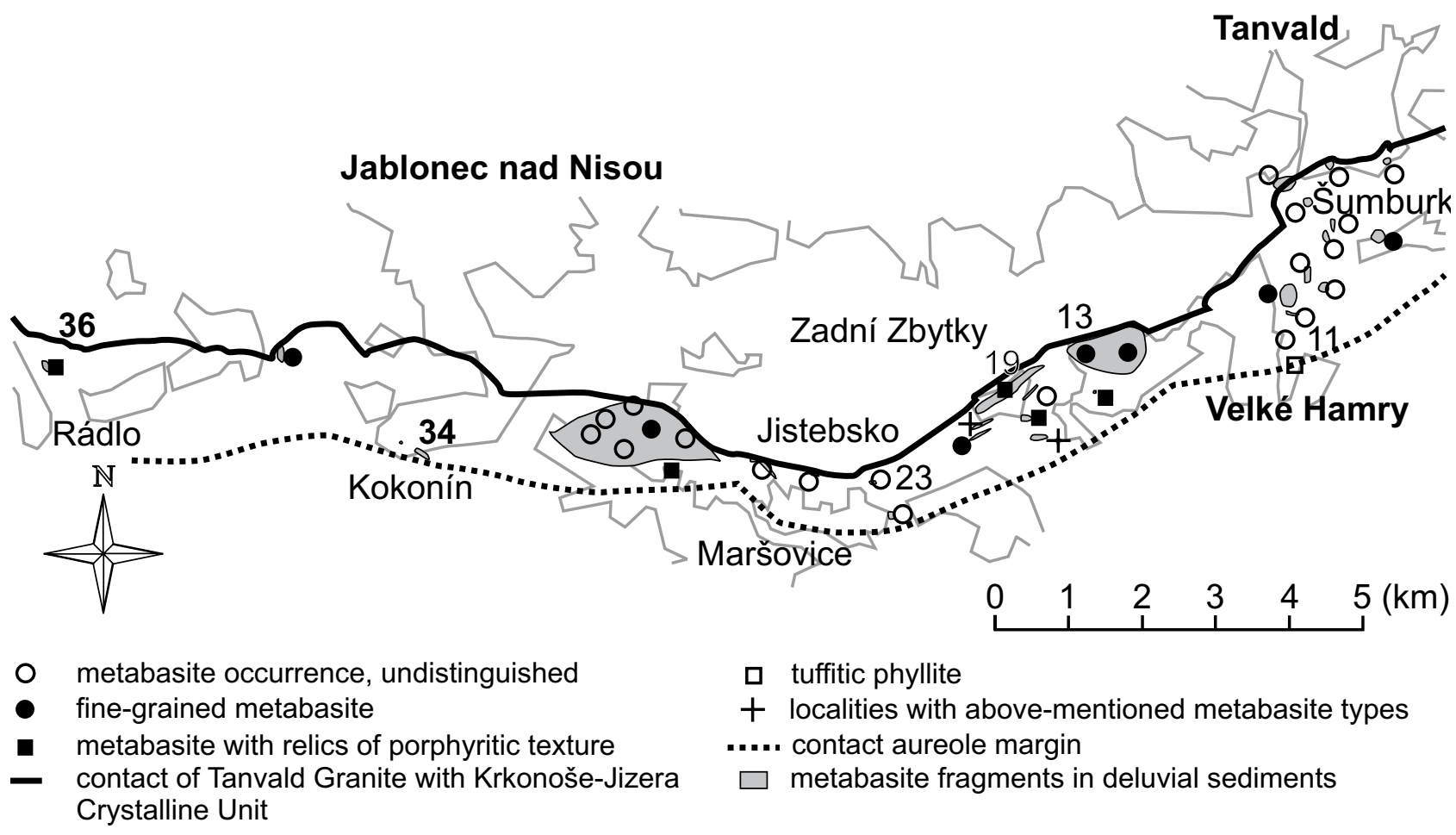

Fig. 3 Areas of metabasite outcrops and places where metabasites occur in Quaternary sediments. Detailed descriptions of marked localities are in Š́da (2007a).

1966; Żelaźniewicz 1997). The stratigraphic range of units in the KJCU and their tectonometamorphic evolution were interpreted in various ways in previous studies due to lack of fossil record and scarce information on the ages of volcanics and intrusive rocks (Kodym and Svoboda 1948; Chaloupský et al. 1989; Chlupáć 1993; Kachlík and Patočka 1998; Marheine et al. 2002; Winchester et al. 2003).

The area of the southern contact of the Tanvald granite and adjacent crystalline unit yielding the metabasite bodies was stratigraphically evaluated during the geological mapping on a scale of $1: 10,000$. The results of this investigation were included in the 1:25,000 scale map sheet 03-322 Jabblonec nad Nisou (Klomínský et al. 2006).

According to the interpretation employed in the map, the metasediments (laminated greyish or greenish chlorite-sericite phyllites, subordinate graphitic phyllites, quartzite intercalations and extremely scarce marbles) with bodies of metabasites in the thermal aureole of the Tanvald granite are interpreted as belonging to the Poniklá Group (in the sense of Winchester et al. 2003) of probably Cambrian to Devonian age (Fig. 1). In the south and southeast, this unit is overthrust by volcano-sedimentary rocks of the Radčice Group, including sericite-chlorite phyllite, chlorite- and chloritoid-rich roofing phyllites, bimodal metavolcanics and intrusives of the Železný Brod Complex (Kachlík in Klomínský et al. 2006).
Recently, Christensen et al. (2006) tried to date metabasites from the Tanvald granite thermal aureole using whole-rock $\mathrm{Rb}-\mathrm{Sr}$ and $\mathrm{U}-\mathrm{Pb}$ isochron methods. Using mainly the whole-rock geochemical and isotopic data, they compared these with metabasites from the Fichtelgebirge and artefacts collected from archaeological sites in the central part of Germany, now held in several museums in Germany. Due to a complicated polymetamorphic evolution and the likelihood of differing protoliths, the authors were not able to precisely determine the age of the metabasites. Rough estimates of c. 1.1-1.2 Ga do not correspond with the local geology and the much younger data obtained for similar rocks in the Železný Brod area and in the Eastern Krkonoše Mts. (Bendl and Patočka 1995; Timmermann et al. 2000; Kozdrój et al. 2005).

\subsection{Distribution and outcrop pattern of metabasites}

Metabasites, also referred to in the old literature as "nephrite, actinolitic schist, actinolite hornfels, hornblende-actinolite hornfels", occur in the southern thermal aureole of the Krkonoše-Jizera Pluton between Rádlo and Prríchovice, in the SE vicinity of the towns of Jablonec nad Nisou and Tanvald in northern Bohemia (Fig. 2). Because the thermal influence of multiple intrusions of 
the Krkonoše-Jizera Plutonic Complex (KJPC) left the strongest imprint on mineral paragenesis and structures of metabasites, the term "hornblende-actinolite hornfels" used by Klomínský et al. (2004) is the most suitable in spite of their partly different protoliths and complicated tectonometamorphic evolution. To avoid terminological problems in descriptions of relicts of magmatic or older metamorphic events, the wider term metabasite is used in this paper to refer to the studied rocks.

The metabasites form thin bodies (from several centimeters to $2 \mathrm{~m}$ ) in various types of thermally metamorphosed siliciclastic sediments (spotted schists grading to andalusite-cordierite-biotite hornfelses). Sediments were folded and metamorphosed during the early phases of the Variscan orogeny and before the intrusion of the late-tectonic Tanvald granite, the age of which is constrained at c. $312 \pm 2 \mathrm{Ma}$ by ${ }^{40} \mathrm{Ar} /{ }^{39} \mathrm{Ar}$ muscovite dating (Marheine et al. 2002). This age could have been partly reset by intrusion of the younger Liberec granite (Klomínský 1969; Klomínský et al. 2007), dated by the $\mathrm{Pb}-\mathrm{Pb}$ evaporation method on zircons at $305 \pm 12 \mathrm{Ma}$ by Kröner et al. (1994, 2001). However, an older age of both the Tanvald and Liberec granites is suggested by the dating of biotite from the Liberec type porphyritic granite at $320 \mathrm{Ma}$ by the ${ }^{40} \mathrm{Ar} /{ }^{39} \mathrm{Ar}$ method (Marheine et al. 2002) and by the age of 330-325 Ma obtained by the $\mathrm{Rb}-\mathrm{Sr}$ whole-rock isochron method (Pin et al. al 1987; Duthou et al. 1991).

The metabasite bodies are relatively thin and dip moderately $\left(15-40^{\circ}\right)$ to the SE-SSE, conformably with the dominant regional metamorphic foliation in the host metasediments. The greenschist-facies schistosity, characterised by muscovite and chlorite, folds the sedimentary bedding, which is reflected in the alternation of fine-grained psammitic or pelitic laminae. This foliation originated as axial planar schistosity to the $\mathrm{E}-\mathrm{W}$ to NW-SE trending folds, well preserved in large outcrops on the left bank of the Kamenice River between the SE margin of Tanvald and Velké Hamry village. The growth of contact metamorphic minerals (cordierite, muscovite, andalusite, biotite, and scarce garnet) often follows the regional metamorphic schistosity, but part of large andalusite porphyroblasts and some biotites grew across it. Intrusion of the Liberec granite probably caused the recrystallization of biotite flakes, replacement of garnet by biotite, and pinitization of cordierite. The fluid activity was connected with a growth of tourmaline in some hornfels types and of wolframite with cassiterite in quartz veins close to the contact with the Tanvald granite at Rádlo (Klomínský and Táborský 2003).

Metabasites crop out on the surface only exceptionally (two outcrops were found during the investigations, NE of Zadní Zbytky and Velké Hamry-Bohdalovice), as seen in Figs 2 and 3. They were mostly studied in situ and only in non-archaeological excavations for construction of houses (Kokonín and Velké Hamry villages), wells (Velké Hamry), waste disposal sites (Rádlo), and some excavations for telephone lines documented during field mapping between Přední and Zadní Zbytky. Detailed descriptions of the sampled localities can be found in the diploma thesis of Šída (2007a).

Metabasite typically forms decimetre-thick intercalations alternating with host metasediments. They mostly exhibit sharp contacts, and only occasionally repeat several times in a profile on a scale of several metres (excavation for a well in Velké Hamry - Fig. 4b). Metabasite body with a thickness exceeding $2 \mathrm{~m}$ was only documented on a well construction site in Velké Hamry.

As follows from the geological mapping, metabasites form several horizons at a distance of several tens to several hundred metres from the contact of Tanvald granite. This distance varies from $1.2 \mathrm{~km}$ in the area of Velké Hamry to $0.2 \mathrm{~km}$ in the area between Zásada and Jistebsko. The width of the metabasite-bearing belt is modified by later NW-SE trending faults. The form of the bodies, thickness of the layers, mutual alternation with metasediments, and lateral extent of the metabasite layers (15 km from Rádlo to the south-western surroundings of Príchovice) support an interpretation that the metabasites may represent original layers of fine-grained volcanoclastic material embedded in a sedimentary sequence. Only thicker layers with relicts of porphyritic texture may represent former sills of alkali basalts.

Three segments with different numbers of metabasite bodies and varied thicknesses may be distinguished within the area studied (Fig. 2). Several small bodies of metabasites in strongly metamorphosed and folded hornfelses occur in the eastern segment between Príchovice and the left bank of the Kamenice River valley in Velké Hamry (Fig. 2). The central segment between Velké Hamry and Maršovický vrch is richest on metabasite occurrences, and up to four thick layers were documented in outcrops and limited excavations. The westernmost part between Kokonín and Rádlo is typically characterised by scarce occurrences of thin metabasite layers. The lateral extent of the metabasites is controlled by NW-SE trending faults.

\section{Overview of localities with evidence of Neolithic mining and stone tool production}

Archaeological finds in Neolithic quarry sites in the Jizera Mountains were discovered in 2002. Thus far, 14 sites with Neolithic artefacts have been found and surveyed (Šrein et al. 2002; Šída et al. 2004a, b; Prostředník et al. 2005; Šída 2005, 2007a), as illustrated in Fig. 3. 

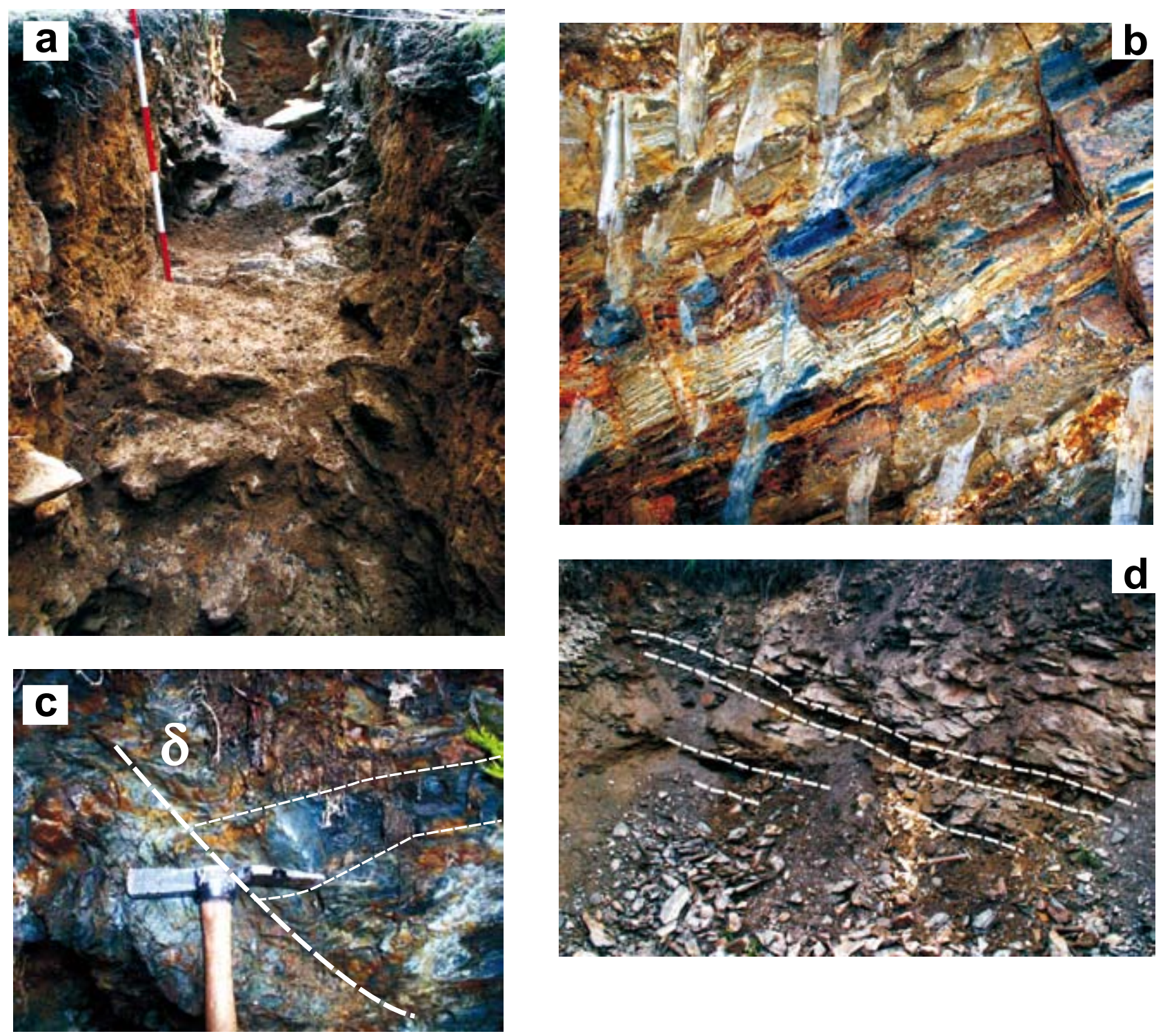

Fig. 4 Archaeological survey sites and patterns of outcrops consisting of thin bodies of metabasites in the thermal aureole of the Tanvald granite. a - Archaeological survey trench at the Jistebsko locality, with evidence of quarrying of fine-grained amphibole-actinolite hornfelses and manufacturing of Neolithic tools (length of visible perch approx. $1 \mathrm{~m}$ ). $\mathbf{b}$ - A layer, several centimetres thick, of fine-grained metabasite alternating with altered cordierite-biotite hornfels in the inner part of the thermal aureole. Water well excavation in Velké Hamry. c - Metabasite intercalation in the weakly metamorphosed biotite hornfels. Pit for house construction, V. Hamry, Bohdalovice. d - Two layers of metabasite in phyllite that is weakly overprinted by contact metamorphism (geological hammer for scale - lower right quadrant).

\subsection{Jistebsko}

The work done by V. Šrein and B. Šreinová culminated in 2001 with the discovery of the undisturbed remains of quarrying activity at a site rich in raw materials. The assumption that this site contains relics of Neolithic age was confirmed by sampling the material and performing a microtrenching and archaeological survey on quarrying field 1 . In 2002 and 2003, some 1700 artefacts were gathered from section 1 (Fig. 4a). Sections 2 to 6 provided similar amounts in the seasons 2004 and 2005. This collection, together with the samples, comprises as many as 4000 Neolithic artefacts. Considering the quarrying and processing that took place at the locality, the composition of finds is relatively uniform (Prostředník et al. 2005).

Most of the artefacts are chronologically unimportant workshop debris. In addition, typical semi-finished Neolithic polished tools can be found. No pottery or chipped stone artefacts made from silicite have been found yet. 
In addition to prominent semi-finished artefacts, chipped coarse tools made from metabasites are present.

The quarry field No. 1 covers an area of $15400 \mathrm{~m}^{2}$ and is the largest preserved relic of Neolithic quarrying. The quarry field No. 2 is situated right on the top of Maršovice Hill and covers $40800 \mathrm{~m}^{2}$ of ground. The quarry field No. 3 is located between the two fields described above and covers $12900 \mathrm{~m}^{2}$.

The area between the quarrying fields has been affected by exploitation and production of artefacts in the past. The area discovered so far as levelled-off in the Middle Ages covers $60380 \mathrm{~m}^{2}$.

\subsection{Maršovice and Kokonín}

The belt containing evidence of the Neolithic industry continues from the Jistebsko cadastre into the neighbouring Maršovice and Kokonín cadastre. For our purposes, however, the whole area can be considered as a single large locality.

The quarry field Maršovice I is the smallest of those found so far on the Maršovice Hill, as it covers an area of $41000 \mathrm{~m}^{2}$. There are some other small areas with remains of quarry pits surrounded by mediaeval fields. Most of the Maršovice area was modified during mediaeval times by the formation of fields.

\subsection{Velké Hamry I}

The site of Velké Hamry I was found and described by Přichystal (2002) and covers an area of $10100 \mathrm{~m}^{2}$. In 2007, relics of small Neolithic quarrying pits covered by alluvial sediments were discovered.

\subsection{Velké Hamry II}

The site was explored by one of the present authors (PŠ) in 2004. It covers an area of $38000 \mathrm{~m}^{2}$. Unfortunately, the entire area yielding artefacts was covered by a village in medieval times, thus any older ground relics were lost. Relics of quarrying pits were discovered during the excavations in 2007.

\subsection{Zásada, Zbytky}

This site was discovered by P. Šída in 2005; it is very similar to the Velké Hamry II site, but it is much smaller.

\section{6. Šumburk nad Desnou}

This small site was discovered by P. Š́da in 2006; the exact extent of this area is so far unknown, though.

\section{Radiocarbon dating of quarry sites}

Two specimens of charcoal were taken in section 1 at the Jistebsko locality (Fig. 4a). Detailed description of individual archaeological layers of this section is drawn in the Fig. 6.3 on page 86 of Śída (2007a). First sample of charcoal came from a channel deposits between the central mound and the deposits of the mound on the side. The second one was sampled on the base of the Neolithic quarry in the same section, where was found a great deal of waste from the manufacture of semi-finished polished tools.

Radiocarbon dating was performed at the VERALaboratory in Vienna. The first sample (number 571) yielded the date VERA-2982 $325 \pm 30$ BP. Calibration of this value yields the period 1480-1650 AD (with 95.4\% probability).

The second sample (number 1717) gave the date VERA-2981 $6120 \pm 35$ BP. Calibration of this value yields the dates 5210-5160 BC (with 14\% probability), 5150-4920 BC (with 79\% probability). While sample No. 1717, connected directly with Neolithic mining activity, is interpreted as being one of the final stages of quarrying at this locality, sample No. 571 is connected with medieval deforestation accompanying settlement and farmland-establishing processes. For a detailed archaeological description and arguments supporting the above interpretations, see Šída (2007a, b).

\section{Rock samples and analytical techniques}

During detailed geological mapping, natural and artificial outcrops were documented from the lithological, structural and archaeological points of view. Fifteen localities with outcrops of the metabasites or vestiges of Neolithic quarrying were found and described in detail (see Śída 2007a). We examined more than 30 thin sections made from samples from these localities. For comparison, samples of metabasites from the Elbtalschiefergebirge deposited in the Sächsische Museum in Dresden and artefacts from several archaeological sites in Moravia were studied under an optical microscope.

Back-scattered electron (BSE) images and major-element analyses of selected minerals from 7 representative samples were obtained using the LINK ISIS 300 Oxford Instruments energy dispersive analyser connected to a CamScan S4 electron microscope at the Faculty of Science, Charles University, Prague. The analytical conditions were 0.991 to $1.014 \mathrm{nA}$ current, $15 \mathrm{kV}$ acceleration voltage, $120 \mathrm{~s}$ counting time.

The mineral chemical data were processed using MinPet software (Richard 1995). 


\section{Petrography of metabasites}

Metabasites at the thermal aureole of Tanvald granite are fine-grained dark-green or black-green rocks, massive or compositionally banded with conchoidal or subconchoidal fractures. Weathered pieces typically have a light grey or whitish weathering crust up to several mm thick.

Typical values of magnetic susceptibility are $0.5-0.8 \times$ $10^{-3}$ SI units, but, at some localities (Kokonín, Bohdalovice and Jeřmanice), susceptibility values are elevated much due to the presence of magnetite, which is also dispersed in some types of host metasediments. According to the mineralogical composition and textures, the metabasites can be divided into two groups: 1) fine-grained, massive metabasites mostly without relics of plagioclase and amphibole phenocrysts, and 2) metabasites with relicts of primary porphyritic textures (Fig. 5). The textural features reflect differences in the protolith as well as in the variable thermal influence of KJPC, depending on true distance from the contact plane. Most of the minerals now present in the rock originated during reactions associated with contact metamorphism. Relics of magmatic minerals (subhedral grains of former ilmenite) and some greenschist-facies metamorphic minerals (chlorite, epidote, alteration product after ilmenite) rarely survived the contact metamorphic recrystallization, mainly in the outer part of the thermal aureole. Srein et al. (2003) found relics of blueschist-facies minerals (barroisite, lawsonite in quartz veins) but these minerals were not observed in our samples. Feldspar, and in rare cases, amphibole with ilmenite preserved their shapes from the previous stages of rock evolution. In contrast, plagioclase is often completely recrystallized due to intense nucleation of new small equant grains, growing probably at the expense of former albite and epidote. Older amphiboles are usually replaced by aggregates of newly formed actinolite and hornblende, and, rarely, cummingtonite. The intergrowth of thin needles of amphiboles, often radially arranged, with plagioclases and ilmenite alteration products in the matrix, gives the rocks their typical mechanical properties, such as strength, resistivity and workability. These textures are most typical of fine-grained, amphibole-rich metabasites free of feldspar phenocrysts.

The mineral assemblages, textural features and other important properties of the rocks are summarized in Tab. 1.

\subsection{Fine-grained massive metabasites mostly without relicts of plagioclase and amphibole phenocrysts}

Fine-grained metabasites are composed of $\mathrm{Mg}$ - or Fehornblende, actinolite, plagioclase $\left(\mathrm{An}_{73-91}\right)$ and alteration products after ilmenite. Light-green chlorite with low birefringence and brown interference colours was present in a significant amount only in sample ZB-472 from Kokonín (Figs 2-3, Tab. 1). This locality is situated in the outer part of the thermal aureole. Apatite, quartz and, less frequently, alteration products after ilmenite, epidote, magnetite and sulphides are present as common accessories. Quartz is often present in thin veinlets and lenses, mainly at localities close to the contact. Actinolite and hornblende form up to $70 \%$ of some samples. The content of plagioclase ranges from 20 to $30 \%$, and ilmenite pseudomorphs account for up to $10 \%$ of the rock. These pseudomorphs are enclosed in amphibole porphyroblasts and also in fine-grained aggregates in the matrix. Hornblende-actinolite pseudomorphs are up to $0.2 \mathrm{~mm}$ long; the matrix grain size is $0.01-0.05 \mathrm{~mm}$. Most samples of this metabasite type show compositional banding, resulting from alternation of monomineralic hornblende-actinolite bands with bands rich in plagioclase with minor quartz. In one of the samples, partly chloritized biotite (Tab. 1) was also present in a local domain. Biotite growth may have resulted from a special microchemistry of metabasite contaminated by a sedimentary component or, more likely, was connected with fluids rich in potassium, released from the Tanvald granite. The biotite laths are strongly replaced by chlorite along the cleavage planes. Hornfelses without compositional banding were the best raw material for manufacturing tools, and the Neolithic quarrying pits were most frequently situated in this material.

\subsection{Metabasites with relicts of primary porphyritic textures}

Metabasites of this type differ from the first group in their texture and mineral composition. The content of amphibole and plagioclase is approximately balanced. Both minerals constitute up to $90-95$ vol. \% of the rock. Ilmenite often occurs in subhedral and skeletal phenocrysts, which are preserved from the magmatic stage. Alteration products after ilmenite form anhedral grains and aggregates disseminated in the matrix. Porphyritic metabasites have higher contents of green or brown-green hornblende, and actinolite is less common than in the fine-grained

Fig. 5 Pairs of photomicrographs (taken in plain polarized light and with crossed polarizers) of various textural types of metabasites from the thermal aureole of the Tanvald granite. a-b Metabasite with preserved porphyritic texture. Hornblende and actinolite pseudomorphs after amphibole phenocrysts. Notice the completely recrystallized plagioclase grains; c-d Fine-grained type of the hornblende-actinolite metabasite. This type of metabasite was the best quality raw material for production of Neolithic tools; e-f Coarse-grained aggregates of ferrohornblende and actinolite replacing former amphibole, amphibole-rich metadolerite; g-h Finer-grained facies of slightly porphyritic metabasite with both amphibole and plagioclase phenocrysts. 

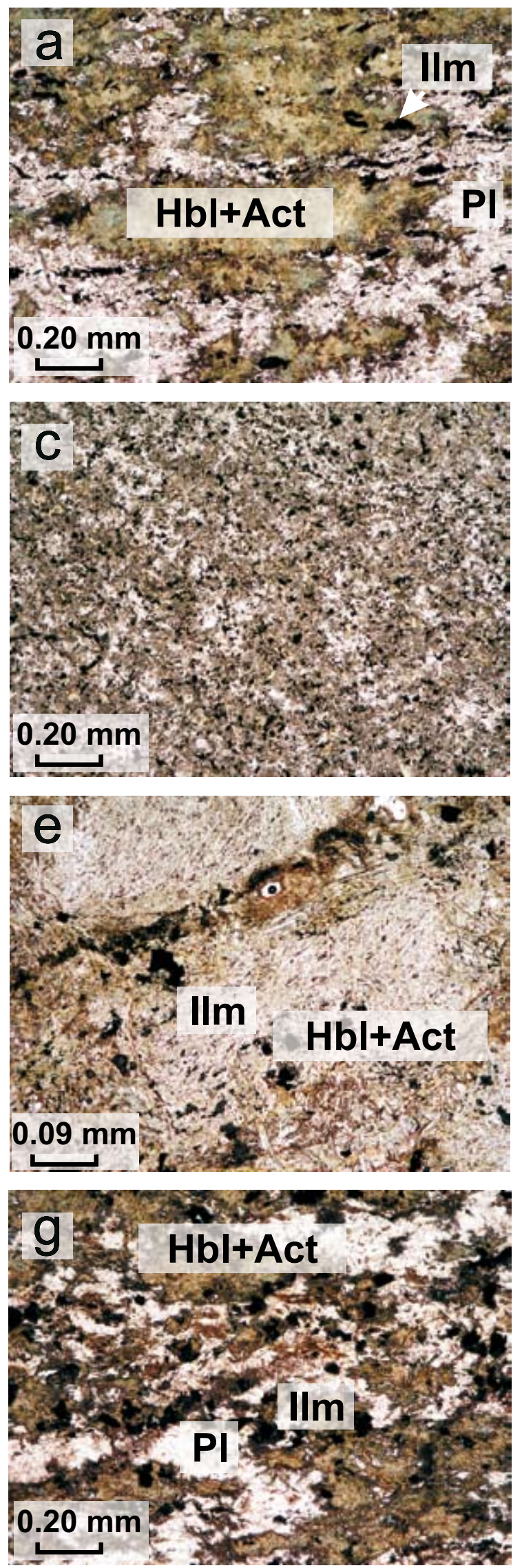
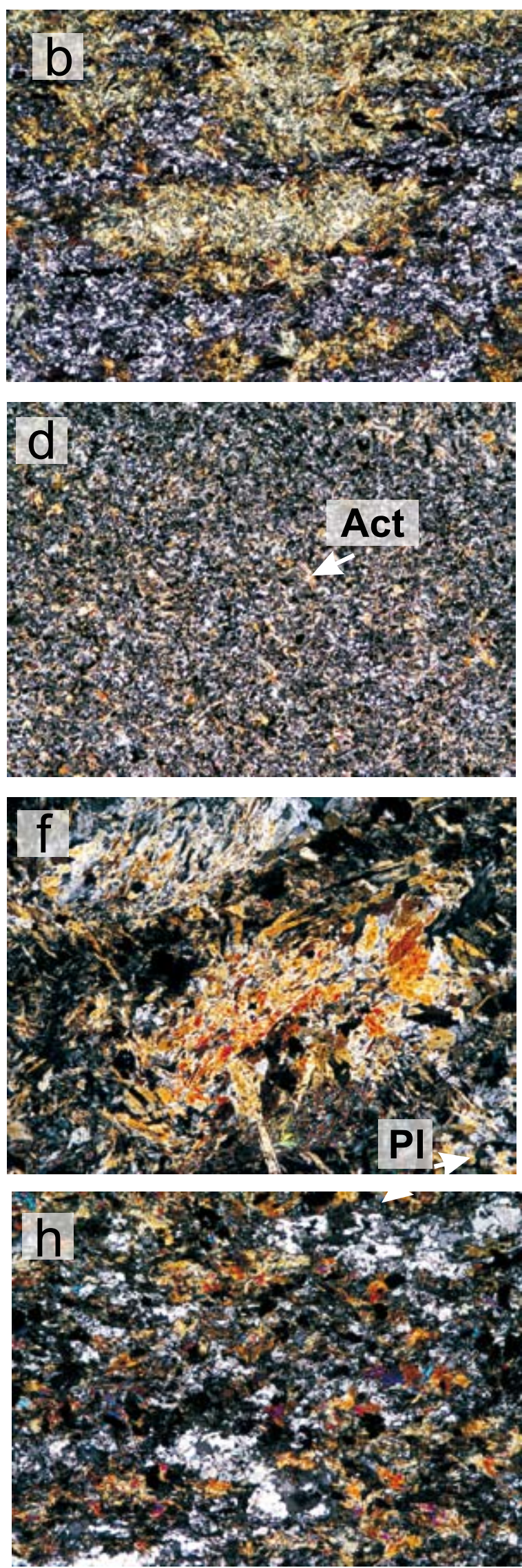
Tab. 1 Petrographic and textural characteristics of metabasites from sampled localities marked in Fig. 4. Explanations: acc. - present in accessory amount, (p) - partially recrystallized feldspar, (c) - completely recrystallized feldspar.

\begin{tabular}{|c|c|c|c|c|c|c|c|c|c|c|c|}
\hline 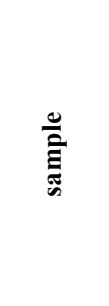 & 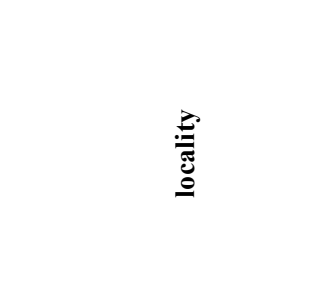 & 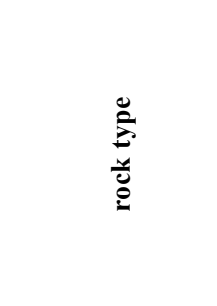 & 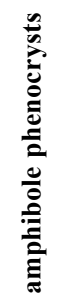 & 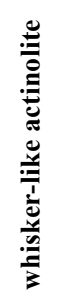 & 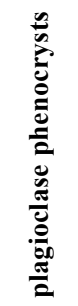 & 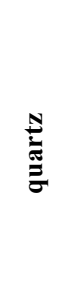 & 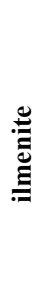 & 总 & $\frac{\stackrel{0}{\mathfrak{n}}}{\frac{0}{2}}$ & $\frac{\frac{0}{0}}{\frac{0}{2}}$ & 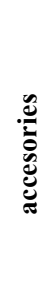 \\
\hline ZB-465 & V. Hamry (loc. No. 11) & tuffite & + & acc. & $+(\mathrm{p})$ & + & + & + & - & + & Ap \\
\hline ZB-466 & V. Hamry (loc. No. 11) & tuff & + & + & $+(\mathrm{p})$ & + & + & + & - & + & Ap \\
\hline ZB-468 & V. Hamry (loc. No. 13) & Act-Hbl hornfels & acc. & + & - & acc. & + & - & - & - & Ap \\
\hline ZB-469 & V. Hamry (loc. No. 13) & metadolerite & + & + & $+(\mathrm{c})$ & - & + & - & - & - & Ap \\
\hline ZB-470 & Zadní Zbytky (loc. No. 19) & Hbl-Act hornfels & + & + & $+(\mathrm{c})$ & - & + & - & - & - & Ap \\
\hline ZB-471 & Rádlo (loc. No. 36) & Hbl-Act hornfels & + & + & + & + & + & - & + & - & Ap \\
\hline ZB-472 & Rádlo (loc. No. 36) & metadolerite & + & + & $+(\mathrm{p})$ & - & + & - & - & + & Ap \\
\hline ZB-473 & Jistebsko (loc. No. 23) & Act-Hbl hornfels & acc. & acc. & - & - & + & - & - & - & Ap \\
\hline ZB-478 & Maršovice & metadolerite & + & + & + & - & + & - & - & + & Ap \\
\hline ZB-487 & Kokonín (loc. No. 34) & Hbl-Act hornfels & acc. & + & - & acc. & + & - & + & + & Ap \\
\hline
\end{tabular}

metabasites. Actinolite is occasionally enclosed in plagioclase phenocrysts or forms randomly oriented aggregates replacing the older amphibole or former pyroxene. Plagioclase is more sodic (andesine to labradorite) compared with that in the fine-grained non-porphyritic metabasite types. Common apatite, scarce epidote, biotite and quartz are accessory phases. Epidote formed by alteration of calcic plagioclase is more common compared to the finegrained variety of metabasites.

The rock is more coarse-grained than massive metabasites, with recrystallized plagioclase phenocrysts reaching sizes of up to $0.8 \mathrm{~mm}$ and amphiboles of up to $0.6 \mathrm{~mm}$ in some samples. Relics of the original ophitic fabric are preserved in samples from the outer part of the aureole (e.g., ZB-472). Porphyritic metabasites probably correspond to the original sills or dykes of dolerites, which are rather common in adjacent tectonostratigraphic units close to the ZBVC.

\section{Mineralogy of metabasites}

Metabasites are scattered from the internal to the external parts of the thermal aureole, where differences in temperature influenced contact metamorphic assemblages. Due to these factors, the mineral associations of both groups of metabasites are quite variable. Porphyritic metabasites, which originated from the alkali basalts with doleritic textures, often carry textures or some minerals from the greenschist-facies stage (epidote and alteration products after ilmenite). Minerals from the contact metamorphic parageneses prevail in fine-grained metabasites.

\subsection{Amphiboles}

Together with plagioclase, amphiboles are the most important constituents of metabasites. At least two compositional types are present in the studied samples, some samples even contained up to four of them. Dominant

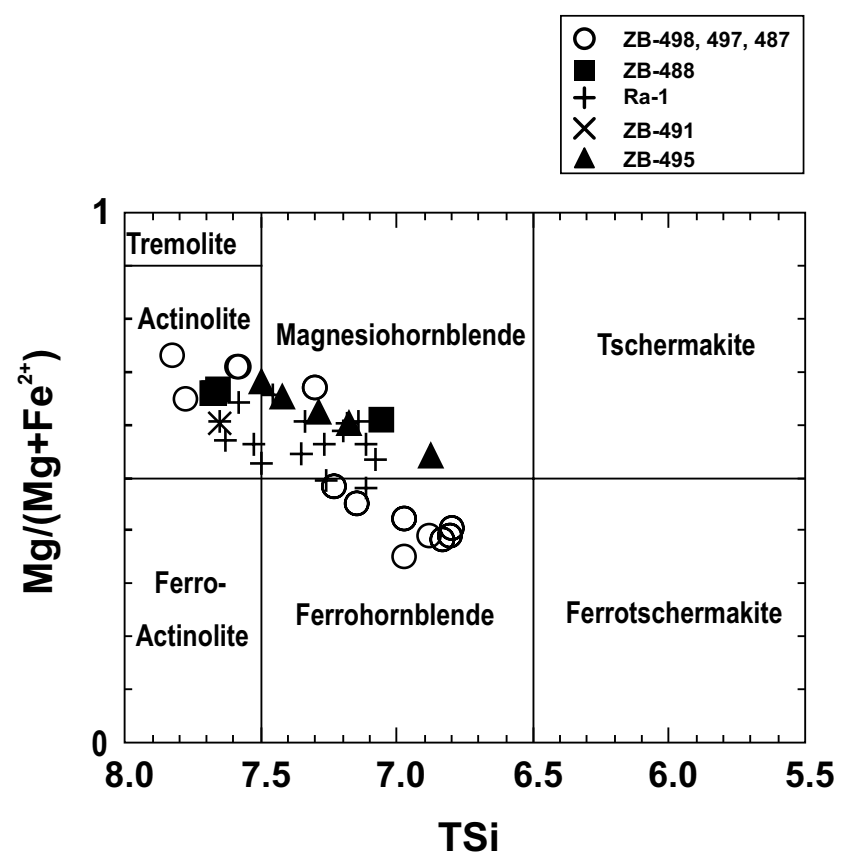

Fig. 6 Plot of amphibole compositions from metabasites from the thermal aureole of the Tanvald granite (classification after Leake et al. 2004). Marked samples include localities of both fine-grained and porphyritic metabasites in different parts of the thermal aureole. 
are monoclinic calcic amphiboles $\left(\mathrm{Ca}_{\mathrm{B}}>1.5 ;(\mathrm{Na}+\mathrm{K})_{\mathrm{A}}\right.$ $\left.<0.50, \mathrm{Ti}<0.50, \mathrm{Ca}_{\mathrm{A}}<0.5\right)$ (Fig. 6, Tab. 2), which are classified as ferrohornblende, magnesiohornblende and actinolite (Leake et al. 2004). The contents of $\mathrm{Si}$ in $\mathrm{T}$ site range between 6.80 and 7.79 ; they have very low $\mathrm{TiO}_{2}(0.2-0.4$ wt \%) and $\mathrm{MnO}(0.10-1.18$ wt \%). The amphiboles have very low contents of alkalis, $(\mathrm{Na}+\mathrm{K})$ A ranging between 0.1 and 0.4 .

The samples from Rádlo, described also by Klomínský et al. (2004), contain small amounts of Fe-Mg amphiboles classified as cummingtonite with $(\mathrm{Ca}+\mathrm{Na})_{\mathrm{B}}<1.00$ and $\left(\mathrm{Mg}, \mathrm{Fe}^{2+}, \mathrm{Mn}\right)>1$. These amphiboles exhibit the highest contents of $\mathrm{FeO}(21.5-22.1 \mathrm{wt} \%)$. Association of magne- siohornblende and actinolite \pm cummingtonite is typical of fine-grained metabasites from the inner part of the aureole. Composition of the associated feldspar ranges from bytownite to anorthite. Ferrohornblende, magnesiohornblende, together with a small amount of actinolite, are more frequent in metadolerite with weaker imprint of contact metamorphism. Hornblende with chlorite and actinolite predominate in the least metamorphosed sample ZB-487 from Kokonín (Tab. 4).

Metabasites with relicts of porphyritic texture mostly contain more hornblende, and their amphiboles are usually rich in $\mathrm{CaO}$. The back-scattered electron images of various textures in metabasites are presented in Fig. 7.

Tab. 2 Representative analyses of amphiboles in metabasites from the thermal aureole of the Tanvald granite, recalculated on the basis of $23 \mathrm{O}$ equivalents. $\mathrm{Fe}^{2+} / \mathrm{Fe}^{3+}$ ratios were calculated following Richard (1995).

\begin{tabular}{|c|c|c|c|c|c|c|c|c|c|}
\hline Sample & ZB-487 & ZB-487 & ZB-487 & ZB-488 & ZB-488 & ZB-498 & ZB-498 & Ra-4 & Ra-5 \\
\hline Analysis & 2 & 2 & 3 & 1 & 2 & 10 & 11 & & 1 \\
\hline Mineral & Act & Act Hbl & Act & Act & Cum & FeHbl & FeHbl & MgHbl & MgHbl \\
\hline $\mathrm{SiO}_{2}$ & 52.27 & 50.79 & 54.68 & 52.85 & 54.16 & 44.49 & 45.99 & 48.29 & 49.57 \\
\hline $\mathrm{TiO}_{2}$ & 0.15 & 0.11 & 0.13 & 0.21 & 0.26 & 0.40 & 0.12 & 0.36 & 0.13 \\
\hline $\mathrm{Al}_{2} \mathrm{O}_{3}$ & 4.36 & 6.48 & 1.75 & 3.31 & 1.38 & 10.62 & 9.67 & 6.48 & 5.93 \\
\hline $\mathrm{FeO}$ & 11.04 & 12.64 & 10.96 & 14.24 & 21.91 & 20.70 & 20.44 & 16.34 & 15.06 \\
\hline MnO & 0.33 & 0.29 & 0.28 & 0.29 & 0.58 & 0.22 & 0.35 & 0.79 & 0.57 \\
\hline MgO & 15.26 & 14.43 & 16.65 & 15.96 & 16.98 & 7.48 & 8.44 & 13.06 & 12.89 \\
\hline $\mathrm{CaO}$ & 12.37 & 12.60 & 12.63 & 9.56 & 2.11 & 11.52 & 10.77 & 9.98 & 11.26 \\
\hline $\mathrm{Na}_{2} \mathrm{O}$ & 0.57 & 1.02 & 0.21 & 0.62 & 0.37 & 0.88 & 0.78 & 1.20 & 1.05 \\
\hline $\mathrm{K}_{2} \mathrm{O}$ & b.d. & 0.05 & 0.00 & 0.02 & b.d & 0.28 & 0.22 & 0.12 & 0.13 \\
\hline Total & 96.32 & 98.41 & 97.29 & 97.06 & 97.71 & 96.59 & 96.78 & 96.64 & 96.71 \\
\hline \multicolumn{10}{|c|}{ Number of atoms } \\
\hline $\mathbf{S i}$ & 7.584 & 7.299 & 7.830 & 7.661 & 7.890 & 6.804 & 6.974 & 7.196 & 7.336 \\
\hline Al & 0.416 & 0.701 & 0.170 & 0.339 & 0.110 & 1.196 & 1.026 & 0.804 & 0.664 \\
\hline$\sum \mathbf{T}$ & 8.000 & 8.000 & 8.000 & 8.000 & 8.000 & 8.000 & 8.000 & 8.000 & 8.000 \\
\hline Al & 0.329 & 0.395 & 0.126 & 0.226 & 0.127 & 0.717 & 0.701 & 0.333 & 0.369 \\
\hline $\mathbf{T i}$ & 0.016 & 0.012 & 0.014 & 0.023 & 0.028 & 0.046 & 0.014 & 0.040 & 0.014 \\
\hline Mg & 3.301 & 3.091 & 3.555 & 3.449 & 3.688 & 1.705 & 1.908 & 2.901 & 2.844 \\
\hline $\mathrm{Fe}^{2+}$ & 1.340 & 1.502 & 1.306 & 1.303 & 1.157 & 2.531 & 2.377 & 1.722 & 1.759 \\
\hline Mn & 0.015 & 0.000 & 0.000 & 0.000 & 0.000 & 0.000 & 0.000 & 0.000 & 0.000 \\
\hline $\mathrm{CCa}$ & 0.000 & 0.000 & 0.000 & 0.000 & 0.000 & 0.000 & 0.000 & 0.000 & 0.000 \\
\hline$\sum \mathbf{C}$ & 5.001 & 5.000 & 5.001 & 5.001 & 5.000 & 4.999 & 5.000 & 4.996 & 4.986 \\
\hline Mg & 0.000 & 0.000 & 0.000 & 0.000 & 0.000 & 0.000 & 0.000 & 0.000 & 0.000 \\
\hline $\mathrm{Fe}^{2+}$ & 0.000 & 0.018 & 0.007 & 0.424 & 1.513 & 0.116 & 0.215 & 0.314 & 0.105 \\
\hline Mn & 0.026 & 0.035 & 0.034 & 0.036 & 0.072 & 0.028 & 0.045 & 0.100 & 0.071 \\
\hline $\mathbf{C a}$ & 1.923 & 1.940 & 1.938 & 1.485 & 0.329 & 1.855 & 1.740 & 1.586 & 1.785 \\
\hline $\mathrm{Na}$ & 0.051 & 0.007 & 0.022 & 0.056 & 0.086 & 0.000 & 0.000 & 0.000 & 0.038 \\
\hline$\sum \mathbf{B}$ & 2.000 & 2.000 & 2.001 & 2.001 & 2.000 & 1.999 & 2.000 & 2.000 & 1.999 \\
\hline $\mathbf{C a}$ & 0.000 & 0.000 & 0.000 & 0.000 & 0.000 & 0.033 & 0.010 & 0.007 & 0.000 \\
\hline $\mathrm{Na}$ & 0.109 & 0.277 & 0.037 & 0.118 & 0.018 & 0.261 & 0.229 & 0.347 & 0.263 \\
\hline $\mathbf{K}$ & - & 0.009 & 0.000 & 0.004 & - & 0.055 & 0.043 & 0.023 & 0.025 \\
\hline$\sum \mathbf{A}$ & 0.104 & 0.286 & 0.037 & 0.122 & 0.011 & 0.348 & 0.282 & 0.377 & 0.288 \\
\hline$\sum$ cations & 15.104 & 15.286 & 15.037 & 15.122 & 15.011 & 15.348 & 15.282 & 15.377 & 15.288 \\
\hline$\sum \mathbf{O}$ & 22.999 & 22.998 & 23.000 & 22.999 & 23.000 & 22.997 & 22.997 & 22.998 & 22.998 \\
\hline
\end{tabular}



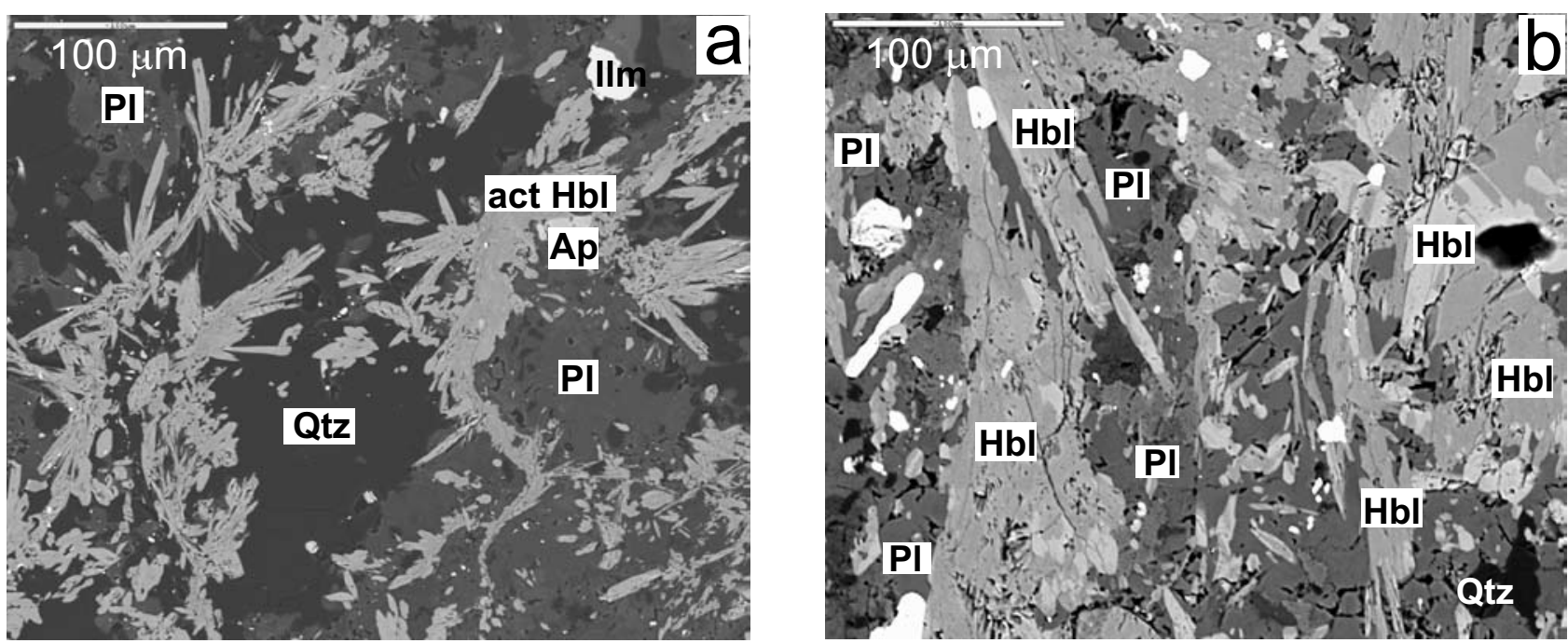

Fig. 7 Back-scattered electron (BSE) images of different textures in metabasites from the thermal aureole of the Tanvald granite. a - Radiating aggregates of actinolite and actinolitic hornblende between veinlets and lenses of hydrothermal quartz. $\mathbf{b}$ - Metabasite with preserved plagioclase and amphibole phenocrysts replaced by large hornblende crystals; plagioclase grains are recrystallized in fine-grained mosaic and small hornblende crystals are enclosed in plagioclase.

\subsection{Feldspars}

Feldspar is the second most common mineral in the finegrained metabasites. The only feldspar in metabasites is plagioclase, except for sample ZB-498, where several grains of K-feldspar were identified.

The composition of plagioclase ranges from albite to anorthite (Fig. 8, Tab. 3). However, albite was identified only in sample ZB-491 from Rádlo. Plagioclase of andesine to labradorite $\left(\mathrm{An}_{30-45}\right)$ composition is typical of metabasites with relics of porphyritic texture. Bytownite to anorthite are the most common feldspars in fine-grained metabasites, but plagioclases of intermediate composition occur also in some samples (ZB-498) in the outer part of the aureole. The microprobe analyses revealed discontinuous reverse zoning in the plagioclase. The inner parts of the grains have the andesine to labradorite composition, partly overgrown by labradorite to anorthite rims. Calcic feldspar growth is connected with the thermal peak of contact metamorphism.

\subsection{Minor and accessory minerals}

Except major minerals like amphiboles and plagioclase, the metabasites contain several minor and accessory mineral phases: ilmenite, chlorite, biotite, titanite, apatite, magnetite and sulphides (pyrite, pyrrhotite, arsenopyrite, chalcopyrite and sphalerite - Šrein et al. 2003).

Ilmenite is present as large subhedral to euhedral grains in metabasites with relicts of doleritic texture. In sample ZB-472, alteration products have replaced most of the original magmatic ilmenite. In the majority of other samples, titanite or unidentified secondary minerals form

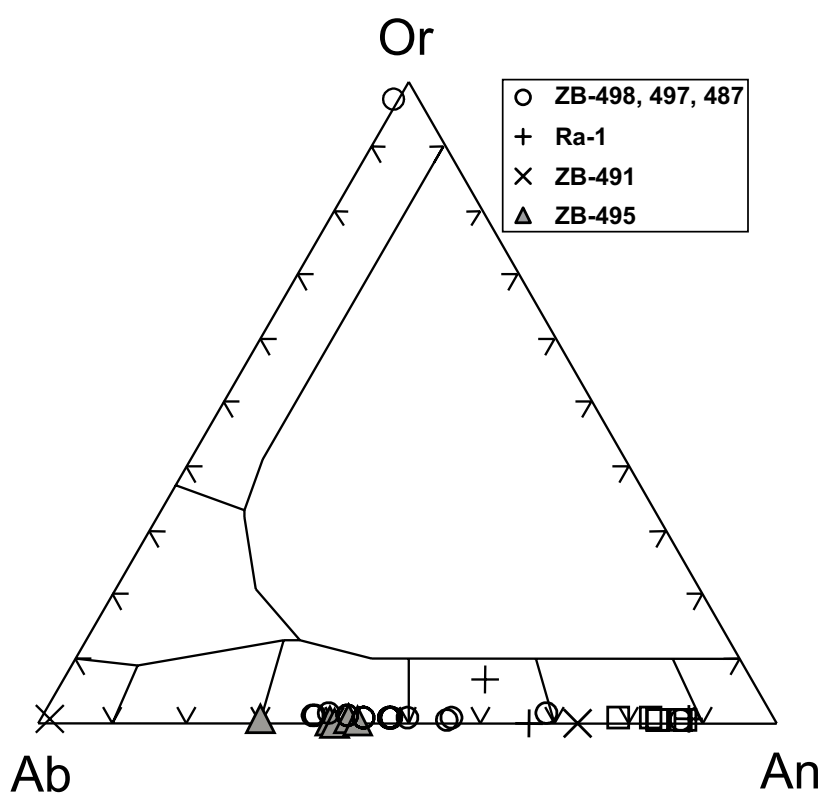

Fig. 8 Composition of plagioclases from metabasites of the Tanvald granite thermal aureole the in the albite-orthoclase-anorthite plot.

only thin rims around larger ilmenite grains. Ilmenite or ilmenite alteration products are present in the fine-grained metabasite mostly as smaller anhedral grains in recrystallized and deformed aggregates in the matrix.

The composition of ilmenite is shown in Tab. 5, and another analysis of ilmenite from Rádlo was published by Klomínský et al. (2004). Ilmenites contain a pyrophanite component (MnO 1.08-6.9 wt \%) and significant amounts of $\mathrm{Fe}_{2} \mathrm{O}_{3}$ (calculated from the stoichiometry); in contrast, the content of $\mathrm{MgO}$ is very low $(0.09-0.26 \mathrm{wt} \%)$. 
Metabasites in a thermal aureole of the Tanvald granite - raw material for the manufacture of Neolithic tools

Titanite replaces magmatic ilmenite along the grain margins. In some metadolerites that show weaker effects of contact metamorphism, the former ilmenite crystals are almost completely replaced by unidentified finegrained secondary minerals. This type of replacement is typical of metadolerites metamorphosed under blueschist- or greenschist-facies conditions in the ZBVC and Ještěd Mts.

Chlorite is present only as minor phase in metabasites, mainly in samples taken from the outer part of the thermal aureole (Zb487 Kokonín), and also in sample ZB-498 from Velké Hamry, which is located close to the contact with the Tanvald granite. The chlorite forms pale green or darker flakes that are intergrown with actinolite or ferrohornblende. The inclusions of ilmenite or other opaque minerals crystallized along the cleavage planes of chlorite. In crossed nicols, the chlorite exhibits anomalous brown or brown-violet interference colours. It seems to be in textural equilibrium with the surrounding amphiboles.

According to the chlorite classification of Bayliss (1975), chlorites from the me-
Tab. 3 Representative analyses of feldspars in studied metabasites, recalculated on the basis of $20 \mathrm{O}$ equivalents.

\begin{tabular}{lcccccccc}
\hline Sample & ZB-488 & ZB-491 & ZB-491 & ZB-495-1 & ZB-495 & ZB-498 & ZB-498 & ZB-498 \\
Analysis & $\mathbf{1}$ & $\mathbf{4}$ & $\mathbf{6}$ & $\mathbf{1}$ & $\mathbf{2}$ & $\mathbf{1 1}$ & $\mathbf{1 3}$ & $\mathbf{1 5}$ \\
\hline $\mathbf{S i O}_{2}$ & 45.73 & 49.60 & 69.05 & 58.00 & 58.88 & 55.27 & 57.50 & 55.92 \\
$\mathbf{A l}_{2} \mathbf{O}_{\mathbf{3}}$ & 33.51 & 32.39 & 20.03 & 27.26 & 26.07 & 28.33 & 26.88 & 28.84 \\
$\mathbf{F e O}$ & 0.30 & 0.55 & 0.08 & b.d. & b.d. & b.d. & b.d. & b.d. \\
$\mathbf{C a O}$ & 18.35 & 15.45 & 0.23 & 9.05 & 8.75 & 10.03 & 9.10 & 10.36 \\
$\mathbf{N a}_{2} \mathbf{O}$ & 1.46 & 3.14 & 11.91 & 6.93 & 7.37 & 5.96 & 6.90 & 6.20 \\
$\mathbf{K}_{2} \mathbf{O}$ & b.d. & b.d. & 0.14 & 0.12 & 0.03 & 0.05 & 0.14 & 0.06 \\
\hline Total & 99.35 & 101.13 & 101.44 & 101.36 & 101.10 & 99.64 & 100.52 & 101.38 \\
\hline $\mathbf{S i}$ & 8.506 & 8.991 & 11.914 & 10.269 & 10.444 & 9.982 & 10.276 & 9.942 \\
$\mathbf{A l}$ & 7.341 & 6.914 & 4.070 & 5.684 & 5.446 & 6.025 & 5.657 & 6.038 \\
Fe & 0.047 & 0.083 & 0.012 & - & - & - & - & - \\
$\mathbf{C a}$ & 3.657 & 3.001 & 0.043 & 1.717 & 1.663 & 1.941 & 1.742 & 1.973 \\
$\mathbf{N a}$ & 0.527 & 1.104 & 3.984 & 2.379 & 2.535 & 2.087 & 2.391 & 2.137 \\
$\mathbf{K}$ & - & - & 0.031 & 0.027 & 0.007 & 0.012 & 0.032 & 0.014 \\
\hline Cations & 20.077 & 20.093 & 20.054 & 20.084 & 20.096 & 20.047 & 20.098 & 20.104 \\
\hline Ab & 12.6 & 26.9 & 98.2 & 57.7 & 60.3 & 51.7 & 57.4 & 51.8 \\
An & 87.4 & 73.1 & 1.1 & 41.6 & 39.5 & 48.0 & 41.8 & 47.8 \\
Or & - & - & 0.8 & 0.7 & 0.2 & 0.3 & 0.8 & 0.3 \\
\hline
\end{tabular}

Tab. 4 Representative analyses of chlorite in studied metabasites, recalculated on basis of $36 \mathrm{O}$ and $16 \mathrm{OH}$ equivalents.

\begin{tabular}{|c|c|c|c|c|c|c|c|}
\hline Sample & ZB-498-1 & ZB-498-13 & ZB-498-15 & ZB-498-17 & ZB-498-2 & ZB-498-6 & ZB-498-8 \\
\hline Analysis & 1 & 13 & 15 & 17 & 2 & 6 & 8 \\
\hline $\mathrm{SiO}_{2}$ & 28.63 & 33.92 & 31.33 & 29.35 & 27.05 & 33.92 & 31.33 \\
\hline $\mathrm{TiO}_{2}$ & 0.23 & 0.05 & 0.09 & b.d. & 0.19 & b.d & b.d. \\
\hline $\mathrm{Al}_{2} \mathrm{O}_{3}$ & 18.91 & 15.73 & 16.79 & 20.19 & 18.53 & 15.73 & 16.79 \\
\hline FeO & 24.94 & 14.46 & 14.95 & 19.27 & 25.23 & 14.46 & 14.95 \\
\hline MnO & 0.06 & 0.05 & 0.16 & 0.15 & 0.27 & 0.05 & 0.16 \\
\hline MgO & 15.77 & 23.94 & 23.45 & 19.47 & 15.45 & 23.94 & 23.45 \\
\hline $\mathrm{CaO}$ & 0.10 & 0.04 & 0.17 & 0.22 & 0.18 & 0.04 & 0.17 \\
\hline $\mathrm{Na}_{2} \mathrm{O}$ & 0.37 & 0.35 & 0.41 & 0.36 & 0.54 & 0.35 & 0.41 \\
\hline $\mathrm{K}_{2} \mathrm{O}$ & 0.86 & 0.08 & b.d. & b.d. & 0.50 & 0.08 & 0.05 \\
\hline $\mathbf{H}_{2} \mathbf{O}^{*}$ & 11.69 & 12.33 & 12.05 & 12.00 & 11.35 & 12.32 & 12.04 \\
\hline Total & 101.55 & 100.85 & 99.44 & 100.89 & 99.28 & 100.79 & 99.34 \\
\hline $\mathbf{S i}$ & 5.875 & 6.600 & 6.236 & 5.867 & 5.714 & 6.604 & 6.242 \\
\hline $\mathbf{A l}^{\mathrm{IV}}$ & 2.125 & 1.400 & 1.764 & 2.133 & 2.286 & 1.396 & 1.758 \\
\hline $\mathrm{AI}^{\mathrm{VI}}$ & 2.444 & 2.205 & 2.171 & 2.619 & 2.324 & 2.211 & 2.180 \\
\hline $\mathbf{T i}$ & 0.036 & 0.007 & 0.013 & 0.000 & 0.030 & 0.000 & 0.000 \\
\hline $\mathbf{F e}^{2+}$ & 4.279 & 2.353 & 2.488 & 3.221 & 4.457 & 2.355 & 2.490 \\
\hline Mn & 0.010 & 0.009 & 0.026 & 0.025 & 0.048 & 0.009 & 0.026 \\
\hline Mg & 4.824 & 6.943 & 6.957 & 5.800 & 4.866 & 6.946 & 6.964 \\
\hline $\mathrm{Ca}$ & 0.021 & 0.009 & 0.036 & 0.046 & 0.041 & 0.009 & 0.036 \\
\hline $\mathbf{N a}$ & 0.145 & 0.132 & 0.158 & 0.140 & 0.221 & 0.132 & 0.158 \\
\hline $\mathbf{K}$ & 0.224 & 0.020 & 0.013 & 0.005 & 0.134 & 0.020 & 0.013 \\
\hline Cations & 19.983 & 19.660 & 19.862 & 19.832 & 20.121 & 19.664 & 19.867 \\
\hline
\end{tabular}

*calculated from stochiometry 
Tab. 5 Representative analyses of ilmenite and apatite in metabasites from the thermal aureole of Tanvald granite. Ilmenite recalculated on basis of $6 \mathrm{O}$ equivalents and apatite of $12 \mathrm{O}$ equivalents.

\begin{tabular}{|c|c|c|c|}
\hline Sample & ZB-498-1 & ZB-498-2 & ZB-495 \\
\hline Analysis & 30 & 31 & 2 \\
\hline $\mathrm{SiO}_{2}$ & 0.38 & 2.69 & 0.42 \\
\hline $\mathrm{TiO}_{2}$ & b.d. & b.d. & 48.32 \\
\hline $\mathrm{Al}_{2} \mathbf{O}_{3}$ & b.d. & b.d. & 0.24 \\
\hline $\mathrm{Fe}_{2} \mathrm{O}_{3}{ }^{*}$ & b.d. & b.d. & 3.54 \\
\hline FeO & 0.44 & 0.60 & 43.73 \\
\hline $\mathrm{MnO}$ & b.d. & b.d. & 1.08 \\
\hline MgO & 0.10 & 0.48 & 0.26 \\
\hline $\mathrm{CaO}$ & 54.52 & 53.15 & 0.40 \\
\hline $\mathrm{Na}_{2} \mathrm{O}$ & b.d. & b.d. & b.d. \\
\hline $\mathbf{K}_{2} \mathbf{O}$ & 0.07 & b.d. & b.d. \\
\hline $\mathbf{P}_{2} \mathrm{O}_{5}$ & 42.11 & 39.27 & b.d. \\
\hline Total & 97.61 & 96.13 & 98.00 \\
\hline $\mathbf{S i}$ & 0.031 & 0.220 & 0.022 \\
\hline $\mathbf{T i}$ & - & - & 1.876 \\
\hline Al & - & - & 0.015 \\
\hline $\mathrm{Fe}^{3+}$ & - & - & 0.138 \\
\hline $\mathrm{Fe}^{2+}$ & 0.030 & 0.041 & 1.888 \\
\hline Mn & - & - & 0.047 \\
\hline Mg & 0.012 & 0.059 & 0.020 \\
\hline $\mathrm{Ca}$ & 4.709 & 4.661 & 0.022 \\
\hline $\mathbf{N a}$ & - & - & - \\
\hline $\mathbf{K}$ & 0.007 & - & - \\
\hline $\mathbf{P}$ & 2.874 & 2.721 & - \\
\hline Cations & 7.662 & 7.696 & 4.027 \\
\hline
\end{tabular}

* calculated from stoichiometry

tabasite are $\mathrm{Mg}$ and Fe chlorite (Tab. 4). Two chlorite groups were distinguished: chlorites rich in $\mathrm{Mg}$ end-member clinochlore, which are richer in $\mathrm{SiO}_{2}$ and poorer in $\mathrm{Al}_{2} \mathrm{O}_{3}$, and chamosite-rich chlorites, which, in contrast with the previous group, are depleted in $\mathrm{SiO}_{2}$ and enriched by $\mathrm{Al}_{2} \mathrm{O}_{3}$.

Biotite occurs only occasionally in samples ZB-464, ZB-474 and it is strongly chloritized on a submicroscopic scale. The strongly pleochroic flakes of biotite are concentrated in a single local domain of the thin section. The $\mathrm{X}_{\mathrm{Fe}}$ of biotite varies between 0.4 and 0.5 , but it may be influenced by chloritization.

Apatite is one of the most common accessory minerals in both types of metabasites that occur in the thermal aureole (Fig. 7). Examples of apatite compositions are given in Tab. 5.

\section{Conditions of contact metamorphism}

Minerals from the magmatic and metamorphic stages and their associated structures were strongly overprinted during the contact metamorphic processes, and relics of the previous regional metamorphic stage are only scarcely preserved.

Metabasite contains actinolite, Fe-Mg hornblende, and, in some cases, cummingtonite in textural equilibrium. The presence of both actinolite and hornblende is known from the greenschist/amphibolite facies transition (Dale et al. 2005 and references therein). Ferrohornblende + actinolite and magnesiohornblende + actinolite may coexist at pressures up to $0.4 \mathrm{GPa}$ within the temperature range of $400-600{ }^{\circ} \mathrm{C}$. The associated plagioclase belongs mostly to labradorite-anorthite.

The temperature of the contact metamorphism reached by the metabasites was estimated using the plagioclase amphibole thermometer of Holland and Blundy (1994), which is based on the edenite + albite $=$ richterite + anorthite reaction. The calculated temperatures, assuming pressures of $0.4 \mathrm{GPa}$ range from $c .550$ to $720{ }^{\circ} \mathrm{C}$, but most of the obtained temperatures fall in the interval $600-700{ }^{\circ} \mathrm{C}$.

The first contact metamorphic minerals in host metasediments are biotite and cordierite. The first appearance of biotite is accompanied by the growth of small cordierite porphyroblasts, according to the reaction muscovite + chlorite + quartz $=$ cordierite + biotite $+\mathrm{H}_{2} \mathrm{O}$. In samples from Rádlo locality, garnet was present in small amounts in some Fe- and Mn-rich protoliths, but it is now completely replaced by biotite. With increasing temperature in inner part of the aureole, the cordierite porphyroblasts became larger and enclosed abundant inclusions of matrix minerals. Growth of skeletal andalusite porphyroblasts was probably associated with the reaction: muscovite + chlorite + quartz $=$ cordierite + andalusite $+\mathrm{H}_{2} \mathrm{O}$. The rocks acquired a typical hornfelsic granolepidoblastic texture, but relicts of older schistosity remain preserved up to the contact.

Because the reaction muscovite + plagioclase + quartz = alumosilicate $+\mathrm{K}$-feldspar $+\mathrm{H}_{2} \mathrm{O}$ was not exceeded, the upper temperature limit for the peak contact metamorphic metapelite assemblage is around $600^{\circ} \mathrm{C}$, according to the P-T grids in the KFMASH system (Spear and Cheney 1989). The above-described assemblages are typical of low-pressure aureoles (up to 0.4 GPa).

\section{Discussion}

\subsection{Comparison of the mineral assemblages and textures of metabasites within the thermal aureole with metabasites from KJCU}

The mineral assemblages of the metabasites are unique in the Czech part of KJCU, especially the fine-grained 
metabasites which were used as a raw material for making stone tools. The porphyritic "metadolerites" overlap texturally with some types of blueschist/greenschistfacies metadolerites from the Železný Brod area, the Ještěd Mts. and the Rýchory Mts., but differ somewhat in the mineral assemblages. Calcic plagioclase (labradorite, anorthite) typically occurs in the fine-grained metabasite from the thermal aureole, while outside the aureole, the metabasites typically contain albite.

While actinolite and hornblende pseudomorphs after older amphibole form sheaf-like or whisker-like aggregates in the amphibole hornfelses, amphiboles in metadolerites outside the aureole are mostly represented by homogeneous larger crystals of actinolite (uralite). Acicular aggregates of amphibole or actinolite typically develop at the margin of large grains of altered amphibole. Parageneses with chlorite, epidote and/or clinozoisite prevail in greenstones and greenschists outside the aureole. Actinolite is mostly a subordinate mineral in greenschist-facies metabasites, but it is relatively common in more massive metadolerites and metagabbros in the Železný Brod area (Patočka et al. 2000). In the Rýchory Mts., where the metamorphic grade reached the lower amphibolite facies, biotite and hornblende is a quite common constituent in effusive metabasites and metadolerites (Patočka et al. 2000). No relics of blueschist-facies minerals have been preserved in the studied metabasites from the thermal aureole, while these occur, albeit rarely, in the metagabbros and metabasites in the Železný Brod area (Fediuk 1962; Cháb and Vrána 1979; Giraud and Burg 1984). The fine-grained basaltic partly amygdaloidal lavas from the Upper Devonian-Lower Carboniferous Jítrava Group have similar fine-grained textures, but contain only greenschistfacies minerals.

The metabasites with relics of porphyritic textures (metadolerites) from the contact zone differ less significantly from similar rock types outside the aureole. They have more calcic feldspar (oligoclase to labradorite); any relics of magmatic amphiboles or pyroxenes are missing. Ilmenite is almost completely altered. Epidote is less common in comparison with the high epidote content of metadolerite outside the aureole. The content of chlorite is much lower, and this mineral is lacking in samples from the inner part of the aureole.

\subsection{Other possible sources of metabasites for making stone tools in the Bohemian Massif}

The exceptional mechanical properties of metabasites in the thermal aureole of the Tanvald granite are caused mainly by the fine-grained textures of primary magmatic or possibly volcanoclastic rocks and the relatively low temperature $\left(c .540-600{ }^{\circ} \mathrm{C}\right)$ during contact metamor- phism. Because of these factors, the stability of the actinolite was not completely exceeded, and thus the actinolite occurs with hornblende in randomly oriented sheaf-like or whisker aggregates. This means that the thermal aureoles of plutonic rocks, where greenschist-to lower amphibolite-facies metabasites occur, represent the best environment for the formation of such rocks. As follows from the study of Neolithic artefacts (Christensen et al. 2006), the metabasites they are made from should have alkali basalt protolith. This is indeed the case for metabasites in the studied area (Patočka et al. 2000).

Their relatively fine-grained texture is an advantage from point of view of the mechanical properties and workability of the future stone tools.

Potential localities of this type of metabasite include other parts of the thermal aureole of KJPC and the German part of the Smrčiny/Fichtelgebirge area where Cambro-Ordovician bimodal volcanic suites occur (Furnes et al. 1994; Siebel et al. 1997; Kachlík and Patočka 1998, Patočka et al. 2000; Christensen et al. 2006; Kachlík 2007). Also, bimodal Devonian to Early Carboniferous suites occur in the Saxothuringian and Rhenohercynian realm (Patočka and Valenta 1996; Kachlík and Patočka 2001; Janoušek et al. 2006; Timmerman et al. 2007 and references therein). For example, two samples from the Maxen (Elbtalschiefergebirge) locality examined by us have very similar texture, but differ in their mineral compositions (higher epidote and chlorite contents). Their contact metamorphic overprint was rather low compared with the thermal aureole of the Tanvald granite. Other localities closer to apophyses of the Meissen Pluton may also be a potential source of similar metabasites. The Devonian bimodal suite in Vrbno Formation and Šternberk-Horní Benešov Belt (Moravia) has to be included in the list of potential source areas as well, in spite of the fact that these metabasites are mostly situated far from Variscan intrusions. In addition, the fibrous amphiboles in greenschists occur in the lower grade parts of the Zábřeh Crystalline Unit, but these localities are far from the thermal aureoles of the Variscan tonalites. The Precambrian greenschists in the roof pendants of the Cadomian Brno Pluton underwent Variscan shearing and do not have alkaline chemistry. The amphibolites from higher grade units of the Bohemian Massif usually exhibit rather well-equilibrated fine- or coarse-grained textures and amphibolite-facies mineralogy, but do not contain fibrous actinolite. Greenschist- to epidote amphibolite-facies in Neoproterozoic basic rocks in the Jílové Zone and in roof pendants of the Central Bohemian Pluton also have different textural and chemical characteristics. From this point of view, it seems most probable that the majority of the artefacts come from the contact of KJPC and possibly from the Smrčiny (Fichtelgebirge) area, as was suggested by Christensen et al. (2006). However, in contrast to Christensen et al. (2006), 
who suggested Neoproterozoic age for the metabasites, the Early Paleozoic (Cambrian to Devonian) protoliths are supported by the new U-Pb zircon ages of metarhyolites and alkali basaltic rocks (Kachlík and Crowley unpublished data). These rocks are an important counterpart of the Cambro-Ordovician and Devonian bimodal volcanic suites occurring in the KJCU.

\subsection{Distribution of actinolite hornfels metabasites in archaeological localities of the Czech Republic and Central Europe}

The geographic distribution of the Jizera Mts. raw material is very different from the distribution of silicites. During the lower and middle Neolithic, this raw material became absolutely dominant in all regions of Bohemia, Moravia and neighbouring Saxony. It predominates in Bohemian localities, for instance Turnov-Maškovy zahrady (Š́́da 2007b), Bylany (Pavlů and Rulf 1991), Horky (Davidová et al. 2004), Kosoř (Šreinová et al. 2000) and at many other sites. In Moravia, we can find it at the Vedrovice site (Přichystal 2002; Šrein pers. com.), where it constitutes more than $95 \%$ of the artefacts, and also at Mohelnice (Tichý pers. com.).

The percentage of various silicite raw materials decreases below $30 \%$ at distances between 70 and $150 \mathrm{~km}$ from the primary source. The picture is completely different for metabasites of the Jizera Mts. type. In southern Moravia, more than $95 \%$ of the raw material comes from the Jizera Mts., i.e. from the distance of more than 250 $\mathrm{km}$. The whole distribution area is still uncertain. We know that, in the lower Neolithic of northern Hessen, these metabasites account for $c .70 \%$ of the raw material, and, in south Hessen, it represents $\sim 50 \%$ (Ramminger 2005). This raw material seems to be dominant at a distance of more than $450 \mathrm{~km}$. There was found no other similar distribution system during the Neolithic period in Central Europe. Recent findings clearly indicate that the distribution system included a wide area of Linear-Band Culture (Bohemia, Moravia, Western Slovakia, southern Poland, Germany including Bavaria and probably northern Austria and The Netherlands).

\section{Conclusions}

The metabasites form relatively thin bodies, from several centimetres up to $2 \mathrm{~m}$ in thickness, intercalated in the host metasedimentary rocks. Based on petrographic investigation, two types of contact-metamorphosed actinolite-hornblende hornfelses were distinguished: 1) fine-grained, amphibole-rich metabasites, which were used for manufacturing Neolithic tools because of their suitable mechanical properties, and 2) metabasites with relics of porphyritic texture.

On the basis of their large lateral extent and intimate alternation with host sediments on a centimetre scale, fine-grained metabasites may have originally represented volcanoclastic rocks (tuffs) or alternatively thin, very fine-grained or glassy dykes, which cooled very quickly. The porphyritic metabasites rich in feldspar correspond to former dolerite sills or dykes.

Host rocks are various types of cordierite-biotite spotted schists in the outer part of the thermal aureole, which pass into coarse-grained andalusite-cordierite-biotite hornfelses close to the contact.

Metabasites contain several types of amphibole, calcic plagioclase (andesine to labradorite) plagioclase and ilmenite. Common minor and accessory phases are apatite, ilmenite or its alteration products, magnetite and sulphides. Quartz, biotite and chlorite are sometimes present in fine-grained metabasites. The two groups differ mainly in plagioclase composition, which is more calcic in finegrained types, and also in their amphibole/plagioclase ratio and textures.

Mineral assemblages of metabasite are mainly a product of contact metamorphic reactions and mineral recrystallization, whereas relicts of magmatic minerals and minerals from older regional metamorphic stages are scarce. Above-mentioned petrographic and mineralogical features distinguish metabasite in the thermal aureole of the KJPC from all other metabasites outside of it. The peak temperatures of contact metamorphism range from 600 to $720^{\circ} \mathrm{C}$, as estimated using the Holland and Blundy (1994) amphibole-plagioclase thermometer, but most of the temperatures that were calculated are scattered between $c$. $600-700{ }^{\circ} \mathrm{C}$ for pressures of $0.4 \mathrm{GPa}$. The absence of Kfs + alumosilicate in the contact metamorphic parageneses and the absence of chlorite and epidote in the peak contact metamorphic assemblage in metabasalts bracket peak metamorphic conditions between c. 540 and $600{ }^{\circ} \mathrm{C}$.

The petrological, geochemical and mineralogical comparison of metabasites from the source area with the material of Neolithic tools found in Germany and southern Moravia provide evidence that the Neolithic tools in Germany primarily originated in the contact zone of KJPC and that the tools were an object of trade over distances of several hundred kilometres.

The contact-metamorphosed Cambro-Ordovician lowgrade metabasites from the contact zone of the Smrčiny granite could be another viable source of metabasites used for tool production in the Bohemian Massif. Similar material could supply Devonian to Lower Carboniferous fine-grained alkali basalts from the Saxothuringian or Rhenohercynian Zone, which underwent greenschistfacies metamorphism and occur in the contact zone of 
Variscan granites. The thermal aureole of the Meissen Massif could be a potential source of these rocks on the basis of certain textural and petrological similarities between basic rocks from Maxen and Ještěd areas.

Acknowledgements We greatly appreciate the constructive and thorough reviews by S. Vrána and M. Murtezi. Their comments and suggestions improved the former manuscript significantly.

This work was funded by grant 269/2006/B-GEO/ PřF provided by the Grant Agency of Charles University, by grant $205 / 07 / 0783$ by Grant Agency of the Czech Republic (V. Kachlík), and by Research Scheme MSM0021620855 (V. Kachlík). The authors are indebted to Dr. J. Klomínský for valuable information about metabasite occurrences and for providing material and photos from the excavation at V. Hamry. We also would like to thank Univ. Prof. Dr. Walter Kutschera, Univ. Prof. Mag. Dr. Eva Wild and Mag. Dr. Peter Steier (Vienna Environmental Research Accelerator Laboratory) for the radiocarbon dating of the samples from the archaeological excavations and R. Procházka (Laboratories of the Geological Departments, Charles University) for assistance during mineral analyses processing.

\section{References}

Bayliss P (1975) Nomenclature of the trioctahedral chlorites. Canad Mineral 13: 178-180

BendL J, РАTOČKA F (1995) The ${ }^{87} \mathrm{Rb} /{ }^{86} \mathrm{Sr}$ isotope geochemistry of the metamorphosed bimodal volcanic association of the Rýchory Mts. Crystalline Complex, West Sudetes, Bohemian Massif. Geol Sudet 29: 3-18

Bukovanská M (1992) Petroarchaeology of Neolithic artefacts from Central Bohemia, Czechoslovakia. Scripta Fac Sci Univ Brun Geol 22: 7-16

СнÁB J, VRÁna S (1979) Crossite-actinolite amphiboles of the Krkonoše-Jizera crystalline complexes and their geological significance. Věst Ústř Úst geol 54: 143-152

Chaloupský J, Červenka J, Jetel J, Králík F, Líbalová J, Píchová E, Pokorný J, Pošmourný K, Sekyra J, Shrbený O, Šalanský J, Šrámek J, Václ J (1989) Geology of the Krkonoše and Jizerské hory Mts. Czech Geological Survey, Prague, pp 1-288 (in Czech with English summary)

ChLupáč I (1993) Stratigraphic evaluation of some metamorphic units in the northern part of the Bohemian Massif. Neu Jb Geol Paläont, Abh 188: 363-388

Christensen AM, Holm PM, Schuessler U, Petrasch J (2006) Indications of a major Neolithic trade route - an archaeometric geochemical and $\mathrm{Sr}, \mathrm{Pb}$ isotope study on amphibolitic raw material from present day Europe. Appl Geochem 21: 1635-1655
Cymmerman Z, Piasecki MA, Seston R (1997) Terranes and terrane boundaries in the Sudetes, northeast Bohemian Massif. Geol Mag 134: 717-725

Dale J, Powell R, White RW, Elmer FL, Holland TJB (2005) A thermodynamic model for $\mathrm{Ca}-\mathrm{Na}$ clinoamphiboles in $\mathrm{Na}_{2} \mathrm{O}-\mathrm{CaO}-\mathrm{FeO}-\mathrm{MgO}-\mathrm{Al}_{2} \mathrm{O}_{3}-\mathrm{SiO}_{2}-\mathrm{H}_{2} \mathrm{O}-\mathrm{O}$ for petrological calculations. J Metamorph Geol 23: 771-791

Davidová T, Š́ída P, Šreinová B, Šrein V (2004) Stone industry from feature 36 in Horky nad Jizerou, district Mladá Boleslav. Archeol ve stř Čechách 8: 193-208 (in Czech)

Duthou JL, Couturie JP, Mierzejewski MP, Pin C (1991) Another dating of granite sample from the Karkonosze Mountains using $\mathrm{Rb}-\mathrm{Sr}$ total rock isochron method. Przegl Geol 36: 75-79 (in Polish with English summary)

Fediuk F (1962) Vulkanity železnobrodského krystalinika. Rozpr Ústř Úst geol 29: 1-116 (in Czech)

Franke W (1989) Variscan plate-tectonics in Central Europe - current ideas and open questions. Tectonophysics 169: $221-228$

Franke W, Żelaźniewicz A (2000) The eastern termination of the Variscides: terrane correlation and kinematic evolution. In: Franke W, HaAk V, Oncken O, Tanner D (eds) Orogenic Processes: Quantification and Modelling in the Variscan Belt. Geol Soc London Spec Publ 179: pp 63-86

Franke W, Żelażniewicz A, Porebski SJ, Wajspyrch B (1993) Saxothuringian Zone in Germany and Poland - differences and common features. Geol Rundsch 82: 583-599

Furnes H, Kryza R, Muszynski, A, Pin C, Garmann LB (1994) Geochemical evidence for progressive, rift-related early Paleozoic volcanism in the western Sudetes. J Geol Soc, London 151: 91-109

GRÄNZER J (1933) Nephrit aus dem Phyllitkontakt im Südwesten des Isergebirgsgranits. Firgenwald 3: 89-96. Liberec

Guiraud M, Burg JP (1984) Mineralogical and petrological study of a blueschist metatuff from the Železný Brod Crystalline Complex, Czechoslovakia. Neu Jb Mineral, Abh 149: 1-12

Holland TJB, Blundy JD (1994) Non-ideal interactions in calcic amphiboles and their bearing on amphiboleplagioclase thermometry. Contrib Mineral Petrol 116: 433-447

HuYER A (1914) Granitkontakt des Schwarzbrunnberges bei Gablonz a. N. Lotos 62: 22-24

HUYER A (1928) Der Granitkontakt des Schwarzbrunngebirges. Mitt Ver Naturfor (Reichenberg) 50: 48-65

Janoušek V, Hanžl P, Aichler J, Pecina V, ERban V, WilímSKÝ D, ŽÁček V, Mixa P, BuRiánková K, Pudilová M, Chlupéčová M (2006) Contrasting petrogenesis of two 
volcanic suites in the Devonian Vrbno Group (Hrubý Jeseník Mts., Czech Republic). Geolines 20: 57-59

Каснці́к V (2006) Poniklá Group (Ordovician-Lower Devonian). In: KlomínskÝ J, Adamová M, Burda J, JaRChOVSKÝ T, Kachlík V, KoŘÁn V, KŘíbek, B, Manová, M, NeKovaŘí Č Š ŠalanskÝ K. Explanations to a basic geological map of Czech Republic 1:25 000 03-322 Jablonec n. Nisou. Czech Geological Survey, Prague, pp 16-18 (in Czech)

KACHLí V (2007). Upper Palaeozoic dyke rocks of the Bohemian part of the Krkonoše-Jizera Crystalline Unit. In: RAPPRICH V, ŘídKOŠIL T (eds) VENTS 2007. Turnov-Sedmihorky. Muzeum Českého ráje, Turnov, pp 12-15

KACHLíK V, РАTOČKA F (1998) Cambrian/Ordovician intracontinental rifting and Devonian closure of the rifting generated basins in the Bohemian Massif realms. Acta Univ Carol, Geol 42: 433-441

KаснLí́ V, РАтос̌Ka F (2001) Late Devonian to Early Carboniferous bimodal volcanic rocks of the Ještěd Range Unit: constraints on the development of the Variscan orogenic wedge. Geolines 13: 74-75

KLOMíNSKÝ J (1969) Granitoid massif of Krkonoše-Jizerské hory. Sbor geol Věd Geol 15: 7-133

KLOMÍNSKÝ J, TÁBORSKÝ Z (2003). Findings of quartz veins with wolframite and cassiterite in exocontact of the Tanvald granite close to Liberec in Northern Bohemia. Uhlí rudy geol průzk 51: 28-30 (in Czech)

Klomínský J, Fediuk F, Schovánek P, Gabašová A (2004) The hornblende-plagioclase hornfels from the contact aureole of the Tanvald granite, northern Bohemia - the raw material for Neolithic tools. Bull Geosci 79: 63-70

Klomínský J, Adamová M, Bělohradský V, Burda J, Kachlík V, Lochmann Z, Manová M, NekovaŘíí Č, NÝvLt D, ŠAlansKÝ K (2006) Explanations to a basic geological map of the Czech Republic 1:25 000 03-143 Liberec. Czech Geological Survey, Prague, pp 1-68 (in Czech)

Klomínský J, Schovánek P, Jarchovský T, Sulovský P, ToužımskÝ M (2007) Contact of Tanvald and Liberec granite at Jablonec nad Nisou. Zpr geol výzk v Roce 2006: 24-29 (in Czech)

Kodym O, Svoboda J (1948) The Caledonian nappiform architecture of the Krkonoše and Jizerske hory Mts.). Sbor Stát geol Úst 15: 109-180 (in Czech with English summary)

Kozdrój W, Turniak K, Tichomirowa M, Bombach K, Kachlík V, Ziolkovska-Kozdrój M (2005) New ${ }^{207} \mathrm{~Pb} /{ }^{206} \mathrm{~Pb}$ zircon ages from the East Krkonoše Metamorphic Complex, West Sudetes - evidence of the Late Cambrian-Early Ordovician magmatism. Geolines 19: 69-70

Kröner A, Hegner E, Hammer J, Haase G, Bielicki KH, Krauss M, Eidam J (1994) Geochronology and Nd-Sr systematics of Lusatian granitoids - significance for the evolution of the Variscan orogen in East-Central Europe. Geol Rundsch 83: 357-376

Kröner A, Jaeckel P, Hegner E, Opletal M (2001) Single zircon ages and whole rock $\mathrm{Nd}$ isotopic systematics of early Palaeozoic granitoid gneisses from the Czech and Polish Sudetes (Jizerské hory, Krkonoše Mountains and Orlice-Sněžník Complex). Int J Earth Sci 90: 304-324

Leake B E, Woolley AR, Birch W D, Burke EA J, Ferraris G, Grice JD, Hawthorne FC, Kisch HJ, Krivovichev VG, Schumacher JC, Stephenson NCN, Whittaker EJW (2004) Nomenclature of amphiboles: additions and revisions to the International Mineralogical Association's amphibole nomenclature. Eur J Mineral 16:191-196.

Marheine D, Kachlík V, Maluski, H, PatočKa F, ŻelaźNIEWICZ A (2002) The Ar-Ar ages from the West Sudetes (NE Bohemian Massif): constraints on the Variscan polyphase tectonothermal development. In: Winchester JA, Pharaoh T, Verniers J (eds) Palaeozoic Amalgamation of the Central Europe. Geol Soc London Spec Publ 201: pp 133-155

Mazur S, Alexandrowsin P, Kryza R, Oberc-Dziedzic T (2006) The Variscan Orogen in Poland. Geol Quart 50: $89-118$

MıLCH L (1902) Beiträge zur Kenntniss der granitischen Gesteine des Riesengebirges. Neu Jb Mineral Geol Paläont Beil-Bd (Stuttgart) 12: 1-15

NAREBSKI W (1994) Lower to Upper Paleozoic tectonomagmatic evolution of NE part of the Bohemian Massif. Zbl Geol Paläont 9-10: 961-972

PATOČKA F, VALENTA J (1996) Geochemistry of the Late Devonian intermediate to acid metavolcanic rocks from the southern part of the Vrbno Group, the Jeseníky Mts. (Moravo-Silesian Belt, Bohemian Massif): paleotectonic implications. Geolines 4: 42-54

PatočKa F, Fajst M, Kachlík V (2000) Mafic-felsic to mafic-ultramafic Early Palaeozoic magmatism of the West Sudetes (NE Bohemian Massif): the South Krkonoše Complex. Z geol Wiss 28: 177-210

Pavlů I, Rulf J (1991) Stone industry from the Neolithic site of Bylany. Památky archeol 82: 277-365 (in Czech)

Pin C, Mierzejewski MP, Duthou JL (1987) Age of the Karkonosze Mts. granite dated by the izochrone $\mathrm{Rb} / \mathrm{Sr}$ and its initial $\mathrm{Sr} / \mathrm{Sr}$ value. Przegl Geol 10: 512-517

Prostředník J, ŠídA P, Šrein V, Šreinová B, ŠŤastnÝ M (2005) Neolithic quarrying in the foothils of the Jizera Mountains and the dating thereof. Archeol rozhl 57: 477-492

PřichYSTAL A (1991) Petrographic study of stone artefacts of Czechoslovak prehistory. In: SOUČEK J (ed) Horniny ve vědách o Zemi. Faculty of Science, Charles University in Prague, pp 19-33 (in Czech)

PŘichystal A (2002) Discovery of Neolithic greenschist quarry in south part of Jizera Mountains (Northern Bohemia). Kvartér (Brno) 8: 12-14 (in Czech) 
RAMMINGER B (2005) Wirtschaftsarchäologische Untersuchungen zu alt- und mittelneolithischen Felsgesteinartefakten in Mittel- und Nordhessen - Archäologie und Rohmaterialbestimmung. Unpublished PhD. Thesis, University of Frankfurt, pp 1-635

RichARD LR (1995) MinPet: mineralogical and petrological data processing system, version 2.02. MinPet Geological Software, Québec, Canada

SchwARz MG, SchneIDER W (1983) Wo liegen die Haupliefergebiete für das Rohmaterial Donaländischer Steinbeile und äxte in Mitteleuropa? Archäol Korrensp16: 29-44

Siebel W, Raschka, H, Irber W, Kreuzer H, Lenz KL, Hohndorf A, WendT I (1997) Early Palaeozoic acid magmatism in the Saxothuringian belt: new insights from a geochemical and isotopic study of orthogneisses and metavolcanic rocks from the Fichtelgebirge, SE Germany. J Petrol 38: 203-230

Svoboda J, Chaloupský J (1966) The West Sudeten Crystalline. In: Svoboda J, DvořáK J, Havlena V, Havlíček V, Horný R, Chlupáč I, Klein V, Kopecký L, Malecha A, Malkovský M, Soukup J, TÁsler R, VÁcl J, ŽEbera K (1966): Regional Geology of Czechoslovakia, I. Czech Geological Survey, Prague, pp 1-668

ŚídA P (2004a) Neolithic and eneolithic stone industry in Upper Jizera River region. In: LuTOvský M (ed) Otázky Neolitu a Eneolitu Našich Zemí 2003, pp 377-408 (in Czech)

ŚíDA P (2004b) Neolithic polished stone industry in Upper Jizera River region. Archeol ve stř Čechách 8: 137-192 (in Czech)

Š́íd P (2005) Additional sites with evidence of Neolithic quarrying and stone tools production in Jizera Mts. Archeol ve stř Čechách 9: 77-102 (in Czech)

SíDA P (2007a) Metabasites of contact aureole of Tanvald granite between Rádlo and Př́chovice used for the manufacture of Neolithic stone tools. Unpublished Diploma Thesis, Charles University in Prague, pp 1-159 (in Czech)

ŚídA P (2007b) The use of stone raw materials in the Neolithic and Eneolithic. The workshop areas of the Upper
Jizera Basin. Dissertationes archaeological Brunenses/ Pragensesque 3, pp 1-282 (in Czech)

SPeAr F, Cheney JT (1989) A petrogenetic grid for pelitic schist in the system $\mathrm{SiO}_{2}-\mathrm{Al}_{2} \mathrm{O}_{3}-\mathrm{FeO}-\mathrm{MgO}-\mathrm{K}_{2} \mathrm{O}-\mathrm{H}_{2} \mathrm{O}$. Contrib Mineral Petrol 101: 149-164

Šrein V, Šreinová B, ŠŤastný M, Šída P, ProstŘedník J (2002) Neolithic quarrying areal on cadaster of Jistebsko village. Archeol ve stř Čechách 6: 91-99 (in Czech)

Šrein V, ŠreinOvá B, ŠŤASTNÝ M (2003) Discovery of unique Neolithic quarrying areal nearby Jistebsko in Northern Bohemia. Bull mineral-petrolog Odd Nár Muz (Praha) 11: 19-32 (in Czech)

Šreinová B, LičKA M, Šrein V, ŠŤAstnÝ M (2000) Mineralogy and petrology of some artefacts from Kosoř near Prague. Krystalinikum 26: 137-143

Šreinová B, ŠŤastný M, Šrein V, ŠídA P (2005) Comparison of chemical composition of amphibole hornfelses in wide environs of the Neolithic production centre near Jistebsko, Jizerské hory. Bull mineral- petrolog Odd Nár Muz 13: 218-224 (in Czech)

Timmerman MJ 2008 Palaeozoic magmatism, In: McCAnn T (ed) The Geology of Central Europe Vol. 1: Precambrian and Palaeozoic: London, Geological Society, pp 665-733

Timmermann H, Parrish RR, Noble SR, Kryza R (2000) New U-Pb monazite and zircon data from the Sudetes Mountains in SW Poland: evidence for a single-cycle Variscan orogeny. J Geol Soc, London 157: 265-268

Winchester JA, Patočka F, Kachlík V, Melzer M, Nowakowski C, Crowley QG, Floyd, P A (2003). Geochemical discrimination of metasedimentary sequences in the Krkonoše-Jizera Terrane (West Sudetes, Bohemian Massif): paleotectonic and stratigraphic constraints. Geol Carpath 54: 267-280

ŻELAźNIEwicz A (1997) The Sudetes as a Palaeozoic orogen in Central Europe. Geol Mag 134: 691-702 